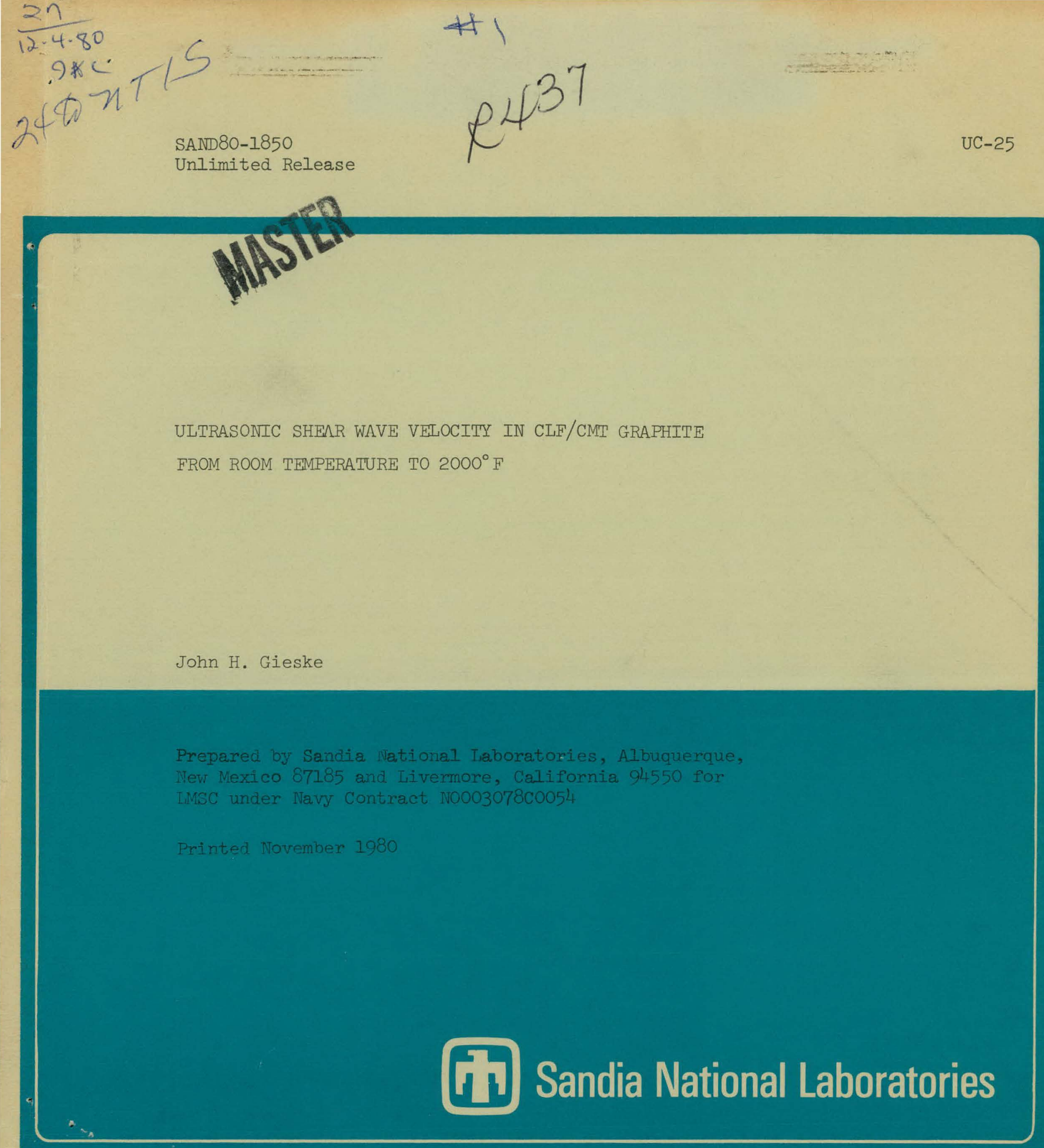

Unlimited Release

ULTRASONIC SHEAR WAVE VELOCITY IN CLF/CMT GRAPHITE

FROM ROOM TEMPERATURE TO $2000^{\circ} \mathrm{F}$

Prepared by Sandia National Laboratories, Albuquerque.

New Mexico 87185 and Livermore, California 94550 for

LMSC under Navy Contract N0003078C0054

Printed November 1980

$S F 290 t-Q(3-80)$ 


\section{DISCLAIMER}

This report was prepared as an account of work sponsored by an agency of the United States Government. Neither the United States Government nor any agency Thereof, nor any of their employees, makes any warranty, express or implied, or assumes any legal liability or responsibility for the accuracy, completeness, or usefulness of any information, apparatus, product, or process disclosed, or represents that its use would not infringe privately owned rights. Reference herein to any specific commercial product, process, or service by trade name, trademark, manufacturer, or otherwise does not necessarily constitute or imply its endorsement, recommendation, or favoring by the United States Government or any agency thereof. The views and opinions of authors expressed herein do not necessarily state or reflect those of the United States Government or any agency thereof. 


\section{DISCLAIMER}

Portions of this document may be illegible in electronic image products. Images are produced from the best available original document. 
Issued by Sandia National Laboratories, operated for the United States Department of Energy by Sandia Corporation.

\section{NOTICE}

This report was prepared as an account of work sponsored by the United States Government. Neither the United States nor the United States Department of Energy, nor any of their employees, nor any of their contractors, subcontractors, or their employees, makes any warranty, express or implied, or assumes any legal liability or responsibility for the accuracy, completeness or usefulness of any information, apparatus, product or process disclosed, or represents that its use would not infringe privately owned rights.

Printed in the United States of America

Available from

National Technical Information Service

U. S. Department of Commerce

5285 Port Royal Road

Springfield, VA 22161

Price: Printed Copy $\$ 4.50$; Microfiche $\$ 3.00$ 


\section{PAGES 1 to 2 WERE INTENTIONALLY LEFT BLANK}


SAND80-1850

UC -25

Unlimited Release

Printed November 1980

\title{
ULTRASONIC SHEAR WAVE VELOCITY IN CLF/CMT GRAPHITE FROM ROOM TEMPERATURE TO $2000^{\circ} \mathrm{F}$
}

John H. Tijeske

Nondestructive Testing. Technology Division 1552

Sandia National Laboratories

Albuquerque, New Mexico 87185

\begin{abstract}
The temperature dependence of the ultrasonic shear velocity in CLF/CMT graphite was determined from room temperature to $2000^{\circ} \mathrm{F}$ using a pulseecho technique. Data are presented for five 0.75 inch diameter specimens all machined from the same CLF/CMT billet. Plots nf ultradonic pulseccho radial and axial scans of the billet which characterize the material property uniformity of the billet are also given.
\end{abstract}

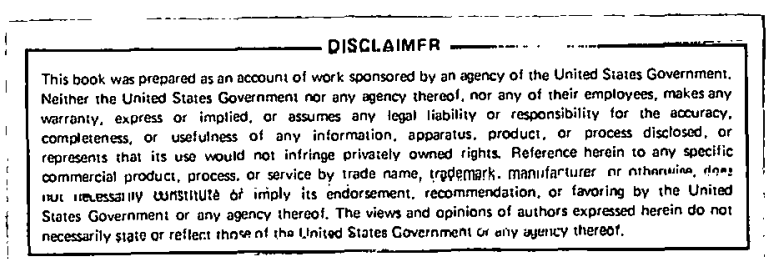


TABLE OF CONTENTS

I. INTRODUCTION

Page

II. ULTRASONIC CHARACTERIZATION OF THE CLF/CMT BILLET

III. EXPERIMENTAL METHODS

IV. TEST RESULTS

V. SUMMARY AND CONCLUSIONS 9

$\begin{array}{ll}\text { APPENDIX A } & 18\end{array}$

$\begin{array}{ll}\text { APPENDIX B } & 24\end{array}$

REFERENCES

LIST OF FIGURES

1. SCHEMATIC DIAGRAM OF THE ELECTRONIC APPARATUS USED FOR RECORDING THE ULTRASONIC WAVE TRACE AND MEASURING THE TIME DETAY DIFFERENCE BETWEEN TWO POINTS OF THE WAVE TRACE

2. SHEAR WAVE VELOCITY VERSUS TEMPERATURE FOR FIVE SPECIMENS FROM BIILET 154J-O4

3. NORMALIZED SHEAR VELOCITY VERSUS TEMPERATURE 12

LIST OF TABLES

1. SHEAR VELOCITY DATA FOR CMMT GRAPHITE SFECIMEN \#2 13

2. SHEAR VELOITY DATA FOR CMT GRAPHITE SPECIMEN \#3 14

3. SHEAR VELOCITY DATA FOR CMT GRAPHITE SHECIMEN \#5, . 15

4. SHEAR VETOCITY DATA FOR CMT GRAPIITE SPECIMEN \#8 16

5. SHEAR VELOCITY DATA FOR CMT GRAPHITE SPECTMEN \#9 17 


\section{Introduction}

The purpose of this work is to supplement the previously reported ultrasonic shear velocity measurements for CMT graphite from room temperature to $6500^{\circ} \frac{\mathrm{F}}{\mathrm{F}}$. For the measurements to $6500^{\circ} \mathrm{F}$, the velocity data from room temperature to $2000^{\circ} \mathrm{F}$ were lacking due to the temperature measuring technique of the $6500^{\circ} \mathrm{F}$ furnace.

The temperature dependence of the ultrasonic shear velocity from room temperature to $6500^{\circ} \mathrm{F}$ is used for the calculation of the ablation of a CMT nose tip of a reentry vehicle as measured by an ultrasonic recession gage. Discrepancies in the calculated real time recession by the ultrasonic gage cumpared w1th àn independently measured recession in laboratory test models, pointed out that a detailed knowledge of the temperature dependence of the ultrasonj.c shear velocity from room temperature to $2000^{\circ} \mathrm{F}$ was necessary.

II. Ultrasonic Characterization of the CLF/CMT Billet

A computerized ultrasonic pulse-echo characterization of the billet was performed prior to fabrication of the test specimens in order to assess the quality of the billet as well as to determine from which areas of the billet to machine specimens for optimum test performance. The complete pulse-echo flaw data, velocity contours, and relative attenuation plots for the billet are shown in Appendix A.

A review of the data in Appendix A indicates that the billet is of good quality. The reflection planes appearing in the axial direction as ceen in the first flaw characlerization plot in Appendix A are normally observed for a CMI billet. The variation of three to four percent in the longitudinal velocity measured in the axial and radial directions across the 
volume of the billet is observed for all CMT billets. The $6 \mathrm{db}$ relative amplitude variation in the radial direction is also normal for a CMT billet. No defects were observed in the billet which should be avoided in machining the 0.75 inch diameter test specimens. The location of each test specimen as it was machined from the billet is shown schematically in Figure $\mathrm{A} 2$.

\section{Experimental Methods}

The ultrasonic technique used for the determination of the shear wave velocity as a function of temperature is the same one used previously ${ }^{1,2}$. A $0.5 \mathrm{MHz}$ shear transducer was coupled to one end of an indexed specimen in the form of a 0.75 inch diameter rod approximately 8 inches long. The indexed section, which provided a one inch gage length for the measurement, was placed in the furnace and the transducer end of the specimen was threaded into a water-cooled brass holder to prevent excessive heating of́ the transducer. The specimen was machined with 30 threads per 1nch over the ent1re length of the specimen to reduce trailing or mode converted wave interference with the echoes of interest. The shear transducer was 1 inch in diameter and was coupled to the specimen using the uncured resin from Hysol Epoxy-Patch \#y34u.

The furnace was a $2000^{\circ} \mathrm{F}$ resistance heating element furnace with a 2 inch diameter bore. The furnace was operated in the vertical position where a constant flow of helium gas was introduced into the top of the furnace which was sealed from the atmosphere. This assured minimum oxidation of the test specimen at the elevated temperatures.

The indexed section of each specimen was made by milling a slot in the side of the specimen to provide a 1.000 inch gage length from the slot to the 
end of the specimen. The slot was machined deep enough so that the reflection from the slot and the end of the rod was approximately equal. Test specimens \#2, \#3, and \#9 were machined with the indexed section at the end of the specimen which corresponded to the lot numbered end of the billet. Test specimens \#5 and \#8 were machined with the index section at the end of the specimen corresponding to the opposite end of the billet. This was done to exhibit any temperature dependent properties of the billet which might exist from orie end of the billet to the other.

The ultrasonic velocity is calculated at each temperature by measuring the delay time difference between the pair of echoes from the slot and the end of the specimen. The velocity is given by

$$
V=2 L / t
$$

where $t$ is the measured delay time and $L$ is the indexed length of the specimen from the slot to the end of the specimen.

The length $L$ at temperature was corrected for thermal expansion using the thermal expansion data ${ }^{3}$ expressed by

$$
\begin{aligned}
\left(\mathrm{L}-\mathrm{L}_{\mathrm{O}}\right) / \mathrm{L}_{\mathrm{O}}= & -.127673 \mathrm{E}-3+.172325 \mathrm{E}-5 \mathrm{~T}+8.74177 \mathrm{E}-10 \mathrm{~T}^{2} \\
& -2.75686 \mathrm{E}-13 \mathrm{~T}^{3}+4.77364 \mathrm{E}-17 \mathrm{~T}^{4}-2.39801 \mathrm{E}-21 \mathrm{~T}^{5}
\end{aligned}
$$

where $\mathrm{T}$ is degrees Fahrenheit and $\mathrm{L}_{\mathrm{o}}$ is the room temperature length. The test temperature was read with a Chromel-Alumel thermocouple placed against the indexed section of the test specimen.

The delay time measurement $t$ between the pair of echoes from the slot and the end of the specimen at each temperature was accomplished with the electronic apparatus shown schematically in Figure 1. At each temperature . determination, the ultrasonic waveform which included the pair of echoes of 
interest was recorded on a X $X$ plotter by using the boxcar integrator. The $\mathrm{X}$ direction of the plotter was calibrated for two microseconds per centimeter with the use of two adjustable start and stop time gates set exactly $30.00 \mu$ seconds apart. The signal of the two gates is recorded on each plot of the ultrasonic waveforms.

The ultrasonic waveform at each temperature determination was plotted on the same graph where the thermocouple temperature and time of day was recorded next to the waveform. The delay time measurement, $t$, used in Equation (1) between the pair of echoes of interest from one waveforms to the next can be calculated directly from the graph. Each delay time measurement $t$ can be determined from the graph with an accuracy of \pm 0.1 usecond which represents an error of no greater than $0.35 \%$ in total delay time.

\section{Test Results}

The ultrasonic waveforms recorded at approximately $100^{\circ} \mathrm{F}$ increments for five test specimens from room temperature to $2000^{\circ} \mathrm{F}$ are shown in Appendix B. Tables 1 through 5 list the temperature, the corrected index length, the measured delay time as read from the graphs of Appendix $B$, and the calculated shear wave velocity using Equation (1). The normalized velocity value at each temperature is also given where the room temperature velocity value for each specimen was taken as the normalizing velocity.

For completeness, decreasing temperature data were also recorded. The decreasing temperature data, however, were accelerated to fit the test mun within the normal working day. Due to the rapid decrease in temperature, thermal equilibrium may not have occurred at all temperatures. 
However, a slower decrease in temperatures was conducted for specimens \#5 and \#8. No significant change in the temperature dependence of the shear wave velocity was observed on decreasing temperature.

The shear wave velocity versus temperature is plotted in Figure 2 for all five test specimens. The spread in the data represents the three to four percent difference in the absolute wave velocity between the five specimens. The temperature dependence of the wave velocity for the five specimens agrees to approximately 1.5\% which can be seen in Flgure 3 where a plot of the normalized velocity versus temperature is given for each specimen.

\section{Summary and Conclusions}

The ultrasonic shear wave velocity was measured in CLF/CMT graphite from room temperature to $2000^{\circ} \mathrm{F}$ in $100^{\circ} \mathrm{F}$ increments. Shear wave velocities were measured for five specimens machined from the same CMT billet where an agreement of 3.5 percent was observed between the specinens over the entire temperature range. The temperature dependence of the normalized shear wave velocity agreed to within 1.5 percent for the five specimens over the entire temperature range. 


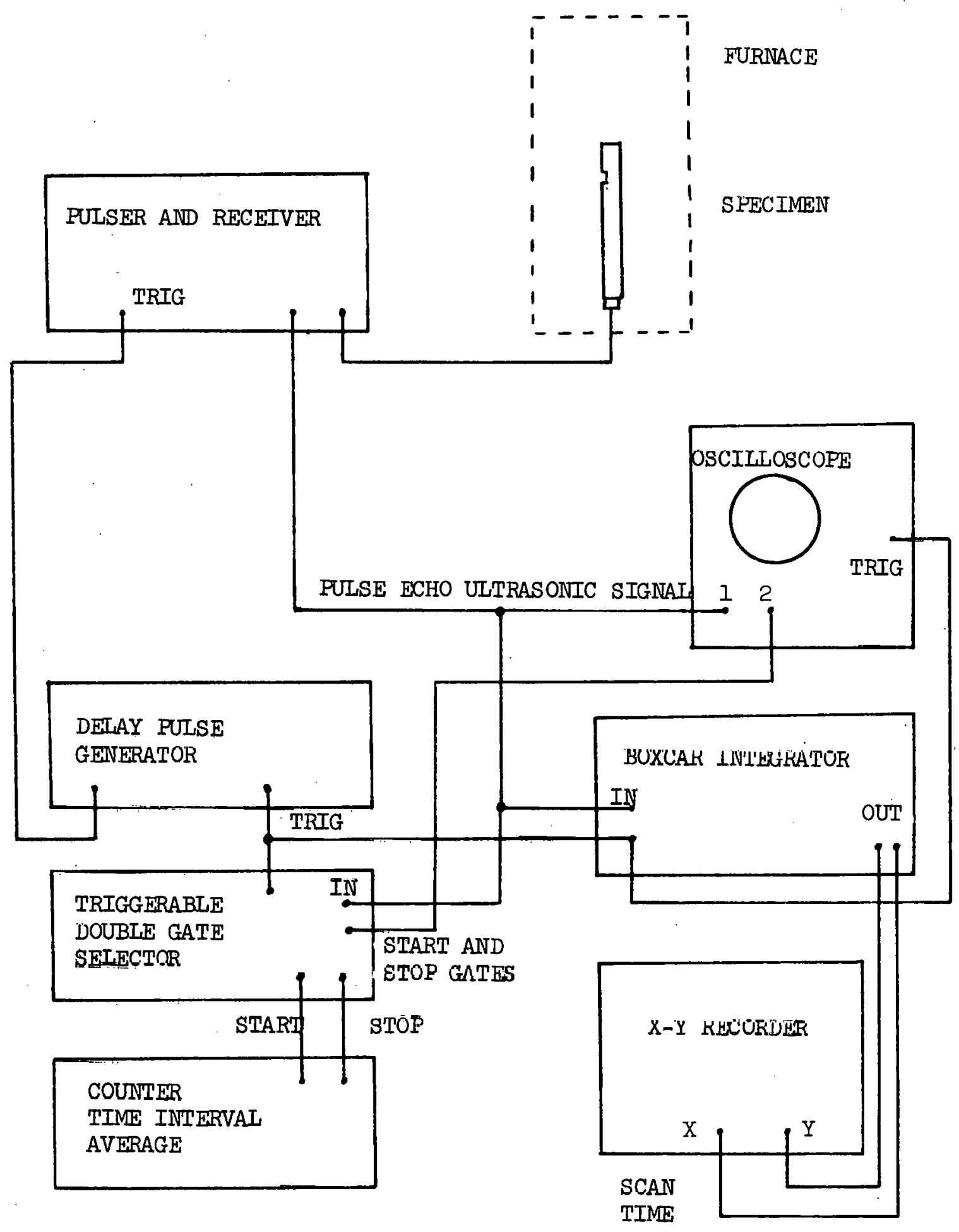

FIGURE 1. SCHEMATIC DTAGRAM OF THE ELECTRONIC APFARATUS USED FOR RECORDING THE ULTRASONIC WAVE TRACE AND MEASURING THE TIME DELAY DIFFERENCE BEIWEEN TWO POINTS OF THE WAVE TRACE. 


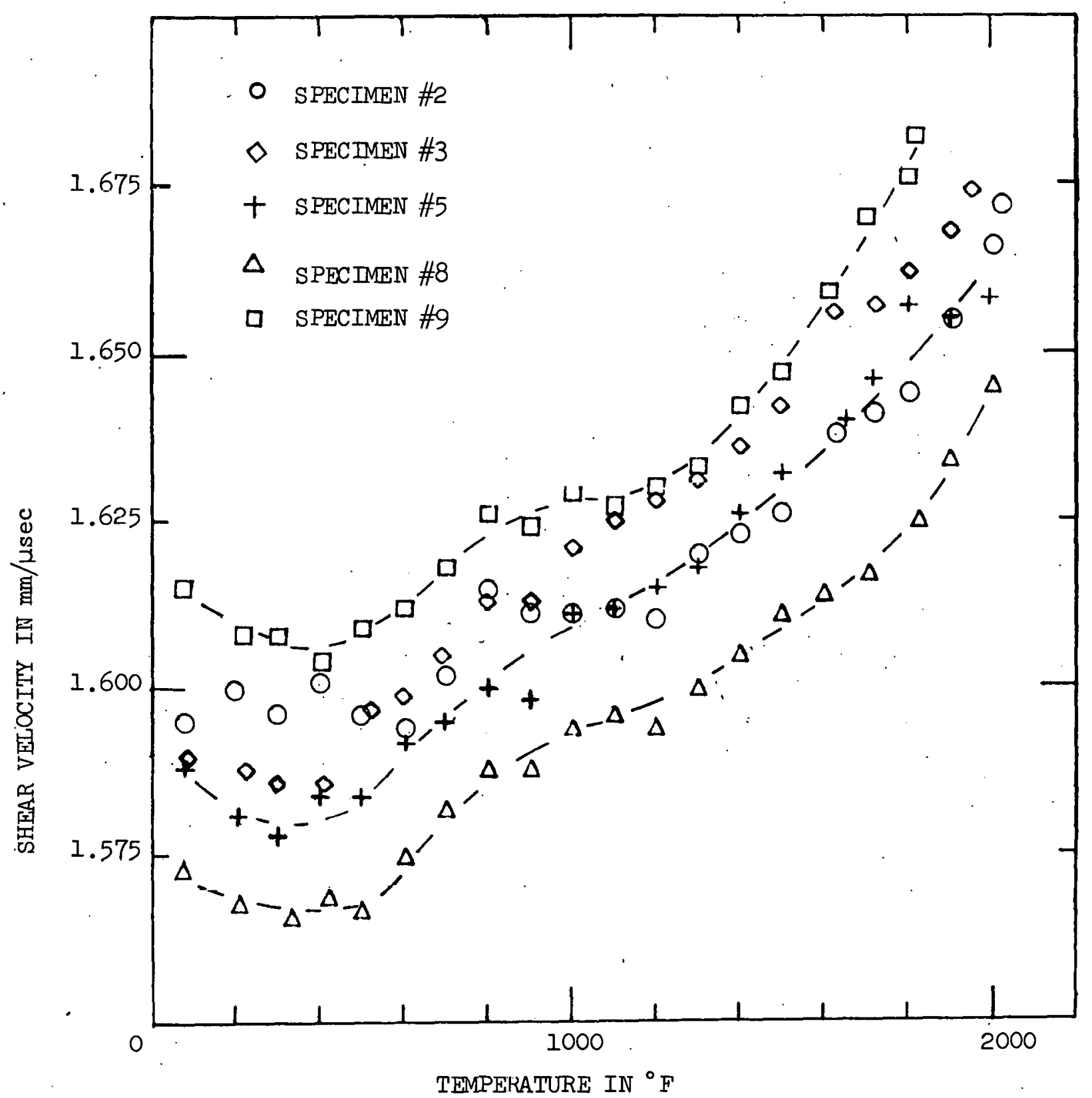

FIGURE 2. SHEAR WAVE VELOCITY VERSUS TEMPERATURE FOR FIVE SPECIMENS FROM BILLET 154J-O4 


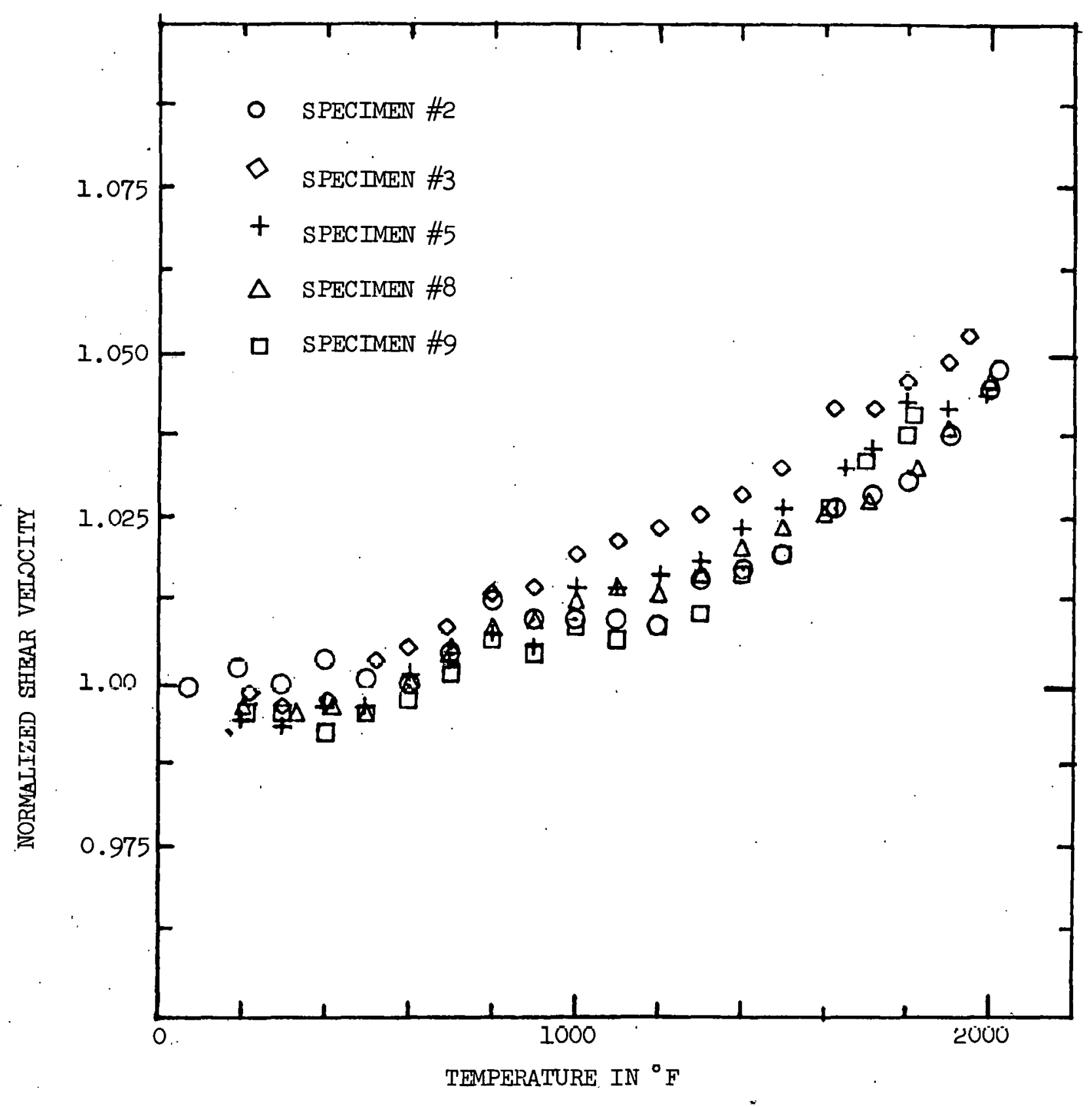

FIGURE 3. NORMALIZED SHEAR VETOCITY VERSUS TEMPERATURE 
TABLE 1 - SHFAR VELOCITY DATA FOR CMT GRAPHITE SPECIMEN \#2

\begin{tabular}{|c|c|c|c|c|}
\hline $\begin{array}{c}\text { DEGREE } \\
\text { F }\end{array}$ & $\begin{array}{c}\text { LENGTH } \\
\text { MM }\end{array}$ & $\begin{array}{c}\text { DET_AY } \\
\text { MICROSEC } \\
\end{array}$ & $\begin{array}{c}\text { VELOCITY } \\
\text { MM/MICROSEC }\end{array}$ & $\begin{array}{l}\text { NORMALIZED } \\
\mathrm{V} / \mathrm{VO} \\
\end{array}$ \\
\hline 77 & 50.801 & 31.85 & 1.595 & $I$ \\
\hline 198 & 50.812 & 31.75 & 1.6 & 1.003 \\
\hline 300 & 50.823 & 31.85 & 1.596 & 1 \\
\hline 401 & 50.835 & 31.75 & 1.601 & 1.004 \\
\hline 501 & 50.847 & 31.85 & 1.596 & 1.001 \\
\hline 605 & 50.86 & 31.9 & 1.594 & 1 \\
\hline 700 & 50.872 & 31.75 & 1.602 & 1.005 \\
\hline 802 & 50.886 & 31.5 & 1.615 & 1.013 \\
\hline 901 & 50.9 & 31.6 & 1.611 & 1.01 \\
\hline 1000 & 50.914 & 31.6 & 1.611 & 1.01 \\
\hline 1100 & 50.928 & 31.6 & 1.612 & 1.01 \\
\hline 1200 & 50.943 & 31.65 & 1.61 & 1.009 \\
\hline 1302 & 50.958 & 31.45 & 1.62 & 1.016 \\
\hline 1404 & 50.974 & 31.4 & 1.623 & 1.018 \\
\hline 1501 & 50.989 & 31.35 & 1.626 & 1.02 \\
\hline 1629 & 51.009 & 31.15 & 1.638 & 1.027 \\
\hline 1721 & 51.023 & 31.1 & 1.641 & 1.029 \\
\hline 1805 & 51.037 & 31.05 & 1.644 & 1.031 \\
\hline 1906 & 51.053 & 30.85 & 1.655 & 1.038 \\
\hline 2001 & 51.069 & 30.65 & 1.666 & 1.045 \\
\hline 2023 & 51.072 & 30.55 & 1.672 & 1.048 \\
\hline 2028 & 51.073 & 30.6 & 1.669 & 1.046 \\
\hline 2000 & 51.069 & 30.5 & 1.674 & 1.05 \\
\hline 1900 & 51.052 & 30.5 & 1.674 & 1.049 \\
\hline 1800 & 51.036 & 30.6 & 1.668 & 1.046 \\
\hline 1700 & 51.02 & 30.65 & 1.665 & 1.044 \\
\hline 1600 & 51.004 & 30.8 & 1.656 & 1.038 \\
\hline 1500 & 50.989 & 30.9 & 1.65 & 1.035 \\
\hline 1400 & 50.973 & 31 & 1.644 & 1.031 \\
\hline 1300 & 50.958 & 31.05 & 1.641 & 1.029 \\
\hline 1200 & 50.943 & 31.1 & 1.638 & 1.027 \\
\hline 1100 & 50.928 & 31.2 & 1.632 & 1.023 \\
\hline 1000 & 50.914 & 31.3 & 1.627 & 1.02 \\
\hline 900 & 50.899 & 31.35 & 1.624 & 1.018 \\
\hline 800 & 50.886 & 31.45 & 1.618 & 1.014 \\
\hline 700 & 50.872 & 31.55 & 1.612 & 1.011 \\
\hline 600 & 50.859 & 31.6 & 1.609 & 1.009 \\
\hline 500 & 50.847 & 31.65 & 1.607 & 1.007 \\
\hline 83 & 50.801 & 31.9 & 1.593 & .998 \\
\hline
\end{tabular}


TABLE 2 - SHEAR VELOCITY DATA FOR CMT GRAPHITE SPECIMEN \#3

\begin{tabular}{|c|c|c|c|c|}
\hline $\begin{array}{c}\text { DEGREE } \\
\mathrm{F} \\
\end{array}$ & $\begin{array}{c}\text { LENGTH } \\
\text { MM } \\
\end{array}$ & $\begin{array}{c}\text { DELAY } \\
\text { MICROSEC } \\
\end{array}$ & $\begin{array}{l}\text { VELOCITY } \\
\text { MM/MICROSEC }\end{array}$ & $\begin{array}{l}\text { NORMALIZED } \\
\mathrm{V} / \mathrm{VO} \\
\end{array}$ \\
\hline 89 & 50.802 & 31.95 & 1.59 & 1 \\
\hline 224 & 50.815 & 32 & 1.588 & .999 \\
\hline 301 & 50.824 & 32.05 & 1.586 & .997 \\
\hline 410 & 50.836 & 32.05 & 1.586 & .998 \\
\hline 523 & 50.85 & 31.85 & 1.597 & 1.004 \\
\hline 599 & 50.859 & 31.8 & 1.599 & 1.006 \\
\hline 690 & 50.871 & 31.7 & 1.605 & 1.009 \\
\hline 797 & 50.885 & 31.55 & 1.613 & 1.014 \\
\hline 900 & 50.899 & 31.55 & 1.613 & 1.015 \\
\hline 1002 & 50.914 & 31.4 & 1.621 & 1.02 \\
\hline & 50.528 & 31.35 & 1.625 & 1.022 \\
\hline 1200 & 50.943 & 31.3 & 1.628 & 1.024 \\
\hline 1299 & 50.958 & 31.25 & 1.631 & 1.026 \\
\hline 1401 & 50.973 & 31.15 & 1.636 & 1.029 \\
\hline 1496 & 50.928 & 31.05 & 1.642 & 1.033 \\
\hline 1624 & 51.008 & 30.8 & 1.656 & 1.042 \\
\hline 1723 & 51.024 & 30.8 & 1.657 & 1.042 \\
\hline 1801 & 51.036 & 30.7 & 1.662 & 1.046 \\
\hline 1900 & 51.052 & 30.6 & 1.668 & 1.049 \\
\hline 1950 & 51.06 & 30.5 & 1.674 & 1.053 \\
\hline 1900 & 51.052 & 30.5 & 1.674 & 1.053 \\
\hline 1800 & 51.036 & 30.6 & 1.668 & 1.049 \\
\hline 1700 & 51.02 & 30.55 & 1.67 & 1.05 \\
\hline 1600 & 51.004 & 30.8 & 1.656 & 1.041 \\
\hline 1500 & 50.989 & 30.7 & 1.661 & 1.045 \\
\hline 1410 & 50.975 & 30.9 & 1.65 & 1.038 \\
\hline 1312 & 50.96 & 30.95 & 1.647 & 1.036 \\
\hline 1208 & 50.944 & 31 & 1.643 & 1.034 \\
\hline 1117 & 50.931 & 31.15 & 1.635 & 1.028 \\
\hline 1025 & 50.917 & 31.1 & 1.637 & 1.03 \\
\hline 912 & 50.901 & 31.25 & 1.629 & 1.024 \\
\hline 190 & 50.884 & 31.3 & 1.626 & 1.022 \\
\hline 6.92 & 50.871 & 31.55 & 1.612 & 1.014 \\
\hline 593 & 50.858 & 31.65 & 1.607 & 1.011 \\
\hline 506 & 50.847 & 31.6 & 1.609 & 1.012 \\
\hline 391 & 50.834 & 31.7 & 1.604 & 1.009 \\
\hline 287 & 50.8222 & 31.6 & 1.608 & 1.012 \\
\hline 198 & 50.812 & 31.8 & 1.598 & 1.005 \\
\hline 92 & 50.802 & 31.8 & 1.598 & 1.005 \\
\hline 92 & 50.802 & 32.1 & 1.583 & .995 \\
\hline
\end{tabular}


TABLE 3 - SHEAR VELOCITY DATA FOR CMT GRAPHITE SPECIMEN \#5

\begin{tabular}{|c|c|c|c|c|}
\hline $\begin{array}{c}\text { DEGREE } \\
\mathrm{F} \\
\end{array}$ & $\begin{array}{c}\text { LENGTH } \\
\text { MM } \\
\end{array}$ & $\begin{array}{c}\text { DELAY } \\
\text { MICROSEC } \\
\end{array}$ & $\begin{array}{l}\text { VEIOOCITY } \\
\text { MM/MICROSEC }\end{array}$ & $\begin{array}{l}\text { NORMALIZED } \\
\mathrm{V} / \mathrm{VO} \\
\end{array}$ \\
\hline 79 & 50.801 & 32 & 1.588 & 1 \\
\hline 205 & 50.813 & 32.15 & 1.581 & .995 \\
\hline 302 & 50.824 & 32.2 & 1.578 & .994 \\
\hline 403 & 50.835 & 32.1 & 1.584 & .997 \\
\hline 498 & 50.847 & 32.1 & 1.584 & .997 \\
\hline 605 & 50.86 & 31.95 & 1.592 & 1.002 \\
\hline 697 & 50.872 & 31.9 & 1.595 & 1.004 \\
\hline 803 & 50.886 & 31.8 & 1.6 & 1.008 \\
\hline 900 & 50.899 & 31.85 & 1.598 & 1.006 \\
\hline 1003 & 50.914 & 31.6 & 1.611 & 1.015 \\
\hline 1100 & 50.928 & 31.6 & 1.612 & 1.015 \\
\hline 1204 & 50.943 & 31.55 & 1.615 & 1.017 \\
\hline 1301 & 50.958 & 31.5 & 1.618 & 1.019 \\
\hline 1401 & 50.973 & 31.35 & 1.626 & 1.024 \\
\hline 1501 & 50.929 & 31.25 & 1.632 & 1.027 \\
\hline 1653 & 51.013 & 31.1 & 1.64 & 1.033 \\
\hline 1718 & 51.023 & 31 & 1.646 & 1.036 \\
\hline$\perp 8 U \perp$ & 51.036 & 30.8 & 1.657 & 1.043 \\
\hline 1900 & 51.052 & 30.85 & 1.655 & 1.042 \\
\hline 1993 & 51.067 & 30.8 & 1.658 & 1.044 \\
\hline 1899 & 51.052 & 30.75 & 1.66 & 1.045 \\
\hline 1799 & 51.036 & 30.8 & 1.657 & 1.043 \\
\hline 1689 & 51.018 & 30.8 & 1.656 & 1.043 \\
\hline 1601 & 51.004 & 30.9 & 1.651 & 1.039 \\
\hline 1494 & 50.988 & 31.05 & 1.642 & 1.034 \\
\hline 1397 & 50.973 & 31.1 & 1.639 & 1.032 \\
\hline 1299 & 50.958 & 31.1 & 1.639 & 1.032 \\
\hline 1196 & 50.942 & 31.2 & 1.633 & 1.028 \\
\hline 1102 & 50.928 & 31.35 & 1.625 & 1.023 \\
\hline 996 & 50.913 & 31.4 & 1.621 & 1.021 \\
\hline 907 & 50.9 & 31.5 & 1.616 & 1.018 \\
\hline 698 & 50.872 & 31.75 & 1.602 & 1.009 \\
\hline 506 & 50.847 & 31.7 & 1.604 & 1.01 \\
\hline 336 & 50.827 & 31.9 & 1.593 & 1.003 \\
\hline 86 & 50.801 & 32.05 & 1.585 & .998 \\
\hline
\end{tabular}


TABLE 4 - SHEAR VELOCITY DATA FOR CMT GRAPHITE SPECIMEN \#8

\begin{tabular}{|c|c|c|c|c|}
\hline $\begin{array}{c}\text { DEGREE } \\
\quad \mathrm{F} \\
\end{array}$ & $\begin{array}{l}\text { LENGTH } \\
\quad \text { MM } \\
\end{array}$ & $\begin{array}{c}\text { DETLAY } \\
\text { MICROSEC } \\
\end{array}$ & $\begin{array}{l}\mathrm{VELOCITY} \\
\mathrm{MM} / \mathrm{NICROSEC}\end{array}$ & $\begin{array}{l}\text { NORMALIZED } \\
\mathrm{V} / \mathrm{VO} \\
\end{array}$ \\
\hline 76 & 50.8 & 32.3 & 1.573 & 1 \\
\hline 209 & 50.814 & 32.4 & 1.568 & .997 \\
\hline 335 & 50.827 & 32.45 & 1.566 & .996 \\
\hline 422 & 50.837 & 32.4 & 1.569 & .997 \\
\hline 500 & 50.847 & 32.45 & 1.567 & .996 \\
\hline 604 & 50.86 & 32.3 & 1.575 & 1.001 \\
\hline 700 & 50.872 & 32.15 & 1.582 & 1.006 \\
\hline 801 & 50.886 & 32.05 & 1.588 & 1.009 \\
\hline 903 & 50.9 & 32.05 & 1.588 & 1.01 \\
\hline 1001 & 50.914 & 31.95 & 1.594 & 1.013 \\
\hline 1100 & 30.928 & 31.9 & 1.596 & 1.015 \\
\hline 1200 & 50.943 & 31.95 & 1.594 & 1.014 \\
\hline 1301 & 50.958 & 31.85 & 1.6 & 1.017 \\
\hline 1401 & 50.973 & 31.75 & 1.605 & 1.021 \\
\hline 1500 & 50.929 & 31.69 & 1.611 & 1.024 \\
\hline 1600 & 51.004 & 31.6 & 1.614 & 1.026 \\
\hline 1708 & 51.021 & 31.55 & 1.617 & 1.028 \\
\hline 1826 & 51.04 & 31.4 & 1.625 & 1.033 \\
\hline $\begin{array}{l}1900 \\
\text { lo }\end{array}$ & 51.052 & 31.25 & 1.634 & 1.039 \\
\hline 2000 & 51.069 & 31.05 & 1.645 & 1.046 \\
\hline 2002 & 51.069 & 31.05 & 1.645 & 1.046 \\
\hline 1897 & 51.052 & 31.05 & 1.644 & 1.045 \\
\hline 1804 & 51.037 & 31.05 & 1.644 & 1.045 \\
\hline 1694 & 51.019 & 31.15 & 1.638 & 1.041 \\
\hline 1593 & 51.003 & 31.2 & 1.635 & 1.039 \\
\hline 1496 & 50.988 & $31.3=$ & 1.629 & 1.036 \\
\hline 14.04 & 50.974 & 31.4 & 1.623 & 1.032 \\
\hline 1304 & 50.958 & 31.45 & 1.62 & 1.03 \\
\hline 1207 & 50.944 & 31.55 & 1.615 & 1.027 \\
\hline 1101 & 50.928 & 31.65 & 1.609 & 1.023 \\
\hline 1000 & 50.914 & 31.75 & 1.604 & $\begin{array}{l}1.019 \\
\end{array}$ \\
\hline 888 & 50.898 & 31.9 & 1.596 & 1.014 \\
\hline 819 & 50.888 & 31.95 & 1.593 & 1.013 \\
\hline $8 i$ & 50.801 & 32.5 & 1.563 & .994 \\
\hline
\end{tabular}


TABLE 5 - SHFAR VELOCITY DATA FOR CMT GRAPHITE SPECIMEN \#9

\begin{tabular}{|c|c|c|c|c|}
\hline $\begin{array}{c}\text { DEGREE } \\
\mathrm{F}\end{array}$ & $\begin{array}{c}\text { LENGTH } \\
\text { MM }\end{array}$ & $\begin{array}{c}\text { DELAAY } \\
\text { MICROSEC }\end{array}$ & $\begin{array}{c}\text { VELOCITY } \\
\text { MM/MICROSEC }\end{array}$ & $\begin{array}{l}\text { NORMALIZED } \\
\mathrm{V} / \mathrm{VO}\end{array}$ \\
\hline 76 & 50.8 & 31.45 & 1.615 & 1 \\
\hline 218 & 50.815 & 31.6 & 1.608 & .996 \\
\hline 301 & 50.824 & 31.6 & 1.608 & .996 \\
\hline 405 & 50.835 & 31.7 & 1.604 & .993 \\
\hline 501 & 50.847 & 31.6 & 1.609 & .996 \\
\hline 601 & 50.859 & 31.55 & 1.612 & .998 \\
\hline 700 & 50.872 & 31.45 & 1.618 & 1.002 \\
\hline 800 & 50.886 & 31.3 & 1.626 & 1.007 \\
\hline 901 & 50.9 & 31.35 & 1.624 & 1.005 \\
\hline 1000 & 50.914 & 31.25 & 1.629 & 1.009 \\
\hline 1100 & 50.928 & 31.3 & 1.627 & 1.007 \\
\hline 1200 & 50.943 & 31.25 & 1.63 & 1.009 \\
\hline 1300 & 50.958 & 31.2 & 1.633 & 1.011 \\
\hline 1401 & 50.973 & 31.05 & 1.642 & 1.017 \\
\hline 1500 & 50.989 & 30.95 & 1.647 & 1.02 \\
\hline 1612 & 51.006 & 30.75 & 1.659 & 1.027 \\
\hline 1702 & 51.02 & 30.55 & 1.67 & 1.034 \\
\hline 1800 & 51.036 & 30.45 & 1.676 & 1.030 \\
\hline 1817 & 51.039 & 30.35 & 1.682 & 1.041 \\
\hline 1794 & 51.035 & 30.4 & 1.679 & 1.039 \\
\hline 1700 & 51.02 & 30.45 & 1.676 & 1.037 \\
\hline 1600 & 51.004 & 30.55 & 1.67 & 1.034 \\
\hline 1500 & 50.989 & 30.6 & 1.666 & 1.032 \\
\hline 1400 & 50.973 & 30.65 & 1.663 & 1.03 \\
\hline 1300 & 50.958 & 30.7 & 1.66 & 1.028 \\
\hline 1200 & 50.943 & 30.8 & 1.654 & 1.024 \\
\hline 1100 & 50.928 & 30.85 & 1.651 & 1.022 \\
\hline 1000 & 50.914 & 30.9 & 1.648 & 1.02 \\
\hline 900 & 50.899 & 30.95 & 1.645 & 1.018 \\
\hline 800 & 50.886 & 31.1 & 1.636 & 1.03 \\
\hline 700 & 50.872 & 31.2 & 1.631 & 1.01 \\
\hline 600 & 30.859 & 31.2 & 1.63 & 1.009 \\
\hline 500 & 50.847 & 31.25 & 1.627 & 1.007 \\
\hline 400 & 50.835 & 31.35 & 1.622 & 1.004 \\
\hline 300 & 50.823 & 31.45 & 1.616 & 1.001 \\
\hline 264 & 50.819 & 31.35 & 1.621 & 1.004 \\
\hline 81 & 50.801 & 31.85 & 1.595 & .988 \\
\hline
\end{tabular}




\section{APPEIVDIX A}

Computerized Pulse Echo UItrasonic Characterization of CMP Billet 154J-04 


\section{TEST\#CMTEE 1}

DATE 520 S०

ECHOES PLOTTEL

WITH ANIILLTTUOESS

IN THE PAHEE

-15 DE TO 6 DE AMFLITUDE

DIAMETEF: 3 IHCHES

THICHHESS $=8.125$ IHLHES

DATA BETWEEN DEPTH OF

.42 IHCHES TO 7.933 IHCHES

TDP UIEW

DEFTH UTEW

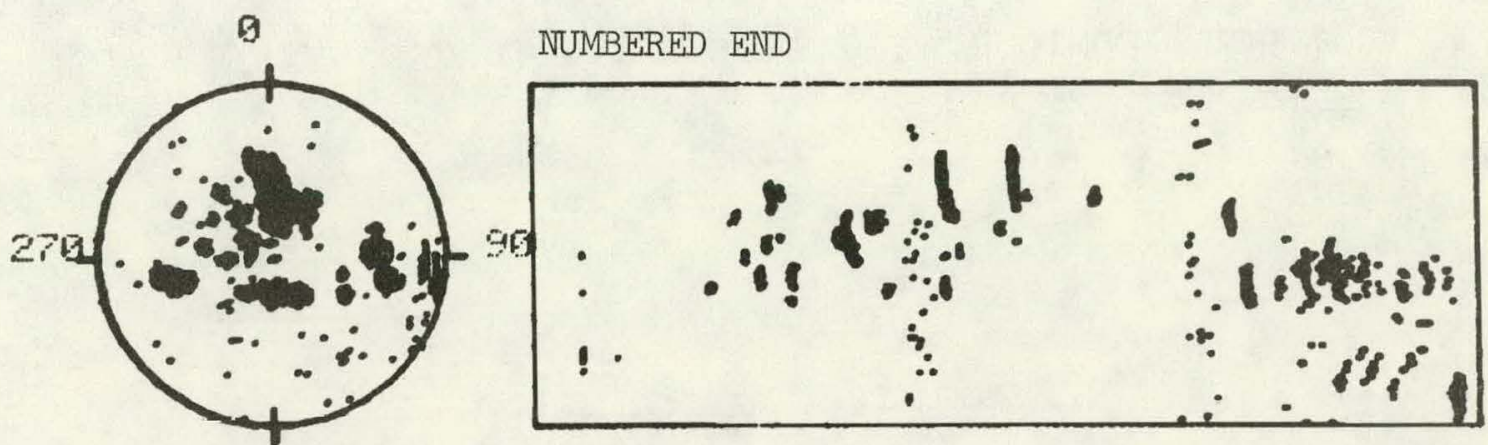

180

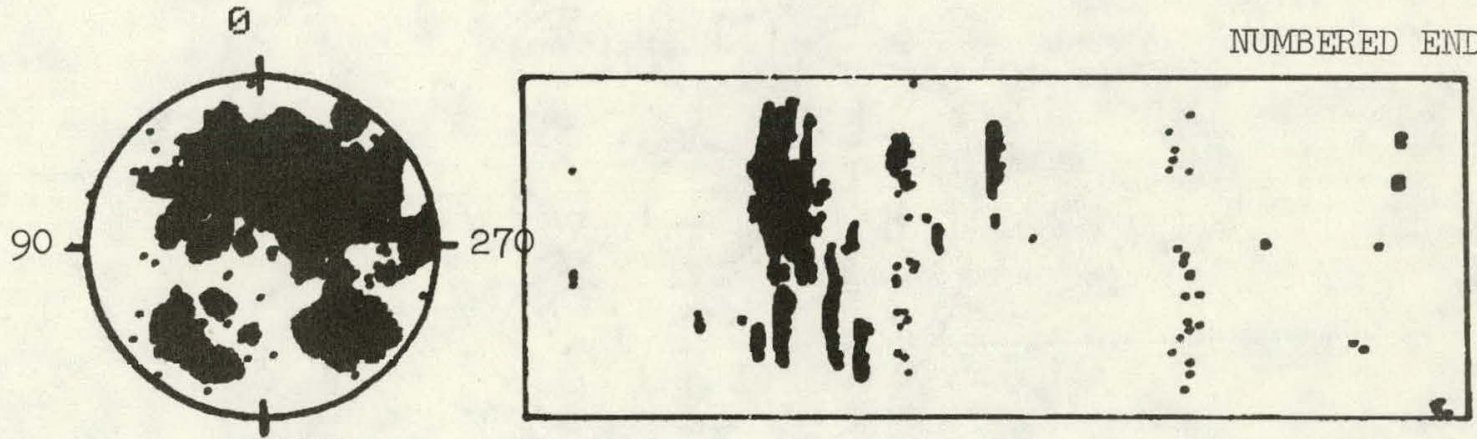

180

PIGUine Al. Pulse Echo Flaw Data resulting from scanning obverse (\# end) and reverse end of the billet with a $1.0 \mathrm{MHz} 1 / 2$ inch transducer. Black areas show small amplitude reflections from planes of abrupt material property variations which are not determental to the integrity of the billet but may distort wave velocity measurement. 
TEST\#CMTEE1

DHTE 520 , 20

ERHDES PLOTTED

WITH AMFLLITUDES

IN THE FAHAE

-15 DE TO O DE AMFLITUDE

DIATHETEP = 3 IHCHES

THICKHESS= 8.125 IHLHES

UELOTITY CONTOUR

$\begin{array}{ll}983 & A \\ .984 & \mathrm{~B} \\ 085 & \mathrm{C}\end{array}$

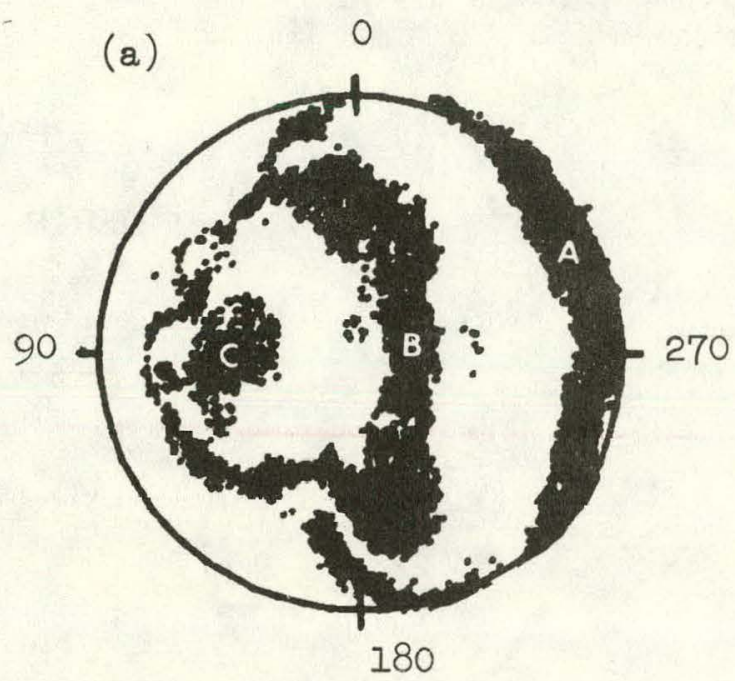

(b)

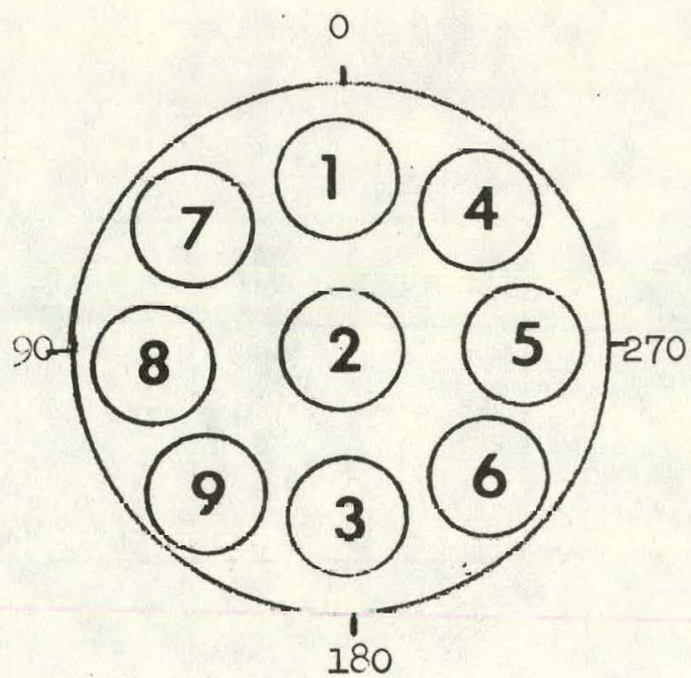

FIGURE A2. (a) Pulse Echo ultrasonic longitudinal velocity contour measurement in Longitudinal Velocity in Axial Direction (across grain) of the axial direction of the billet. (b) Approximate locations in billet from which $3 / 4$ inch diameter test specimens were machined. 
TEST\#INTA1

DATE 513 G

ECHOES PLOTTED

WITH ATIFLITUDLES

IN THE REATISE

-15 DE TD 5 DE

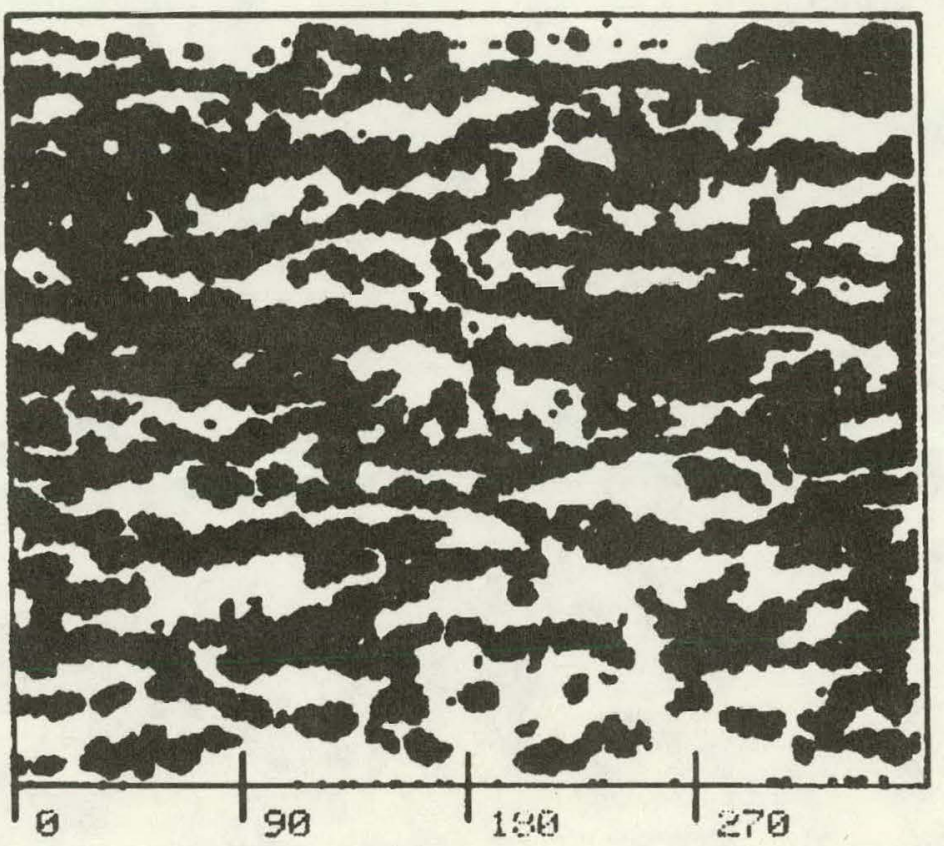

FIGURE A3. Ultrasonic pulse echo relative attenuation in the radial direction of the billet. Large variations of the ultrasonic echo amplitude are recorded but are not unusual for a CMT billet. Black shows locations where the signal amplitude was at least $6 \mathrm{db}$ above the signal at the white areas. Numbered end of billet is at the bottom of the plot. 
TEST\#CMTU1

DATE $5 \quad 14 \quad 86$

ECHIIES PLOTTED

WITH AMHLITUCIES

IH THE RAHHGE

-15 CB TO 0 DB

YELDEITY LABEL

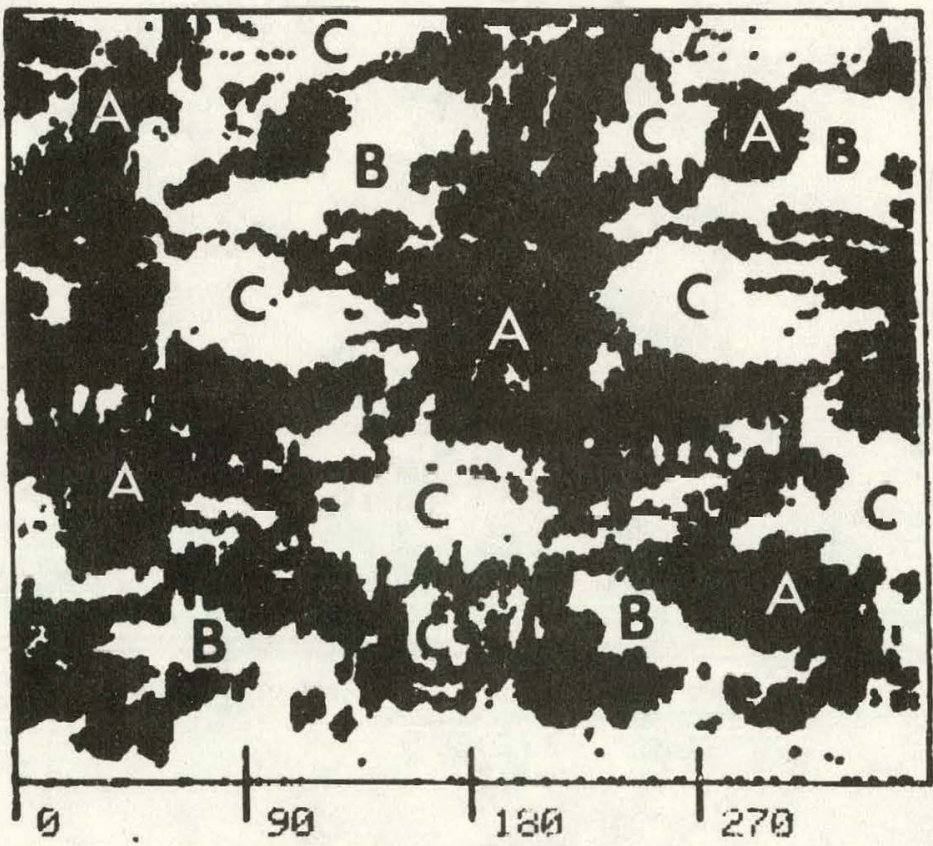

FIGURE $\Lambda$. Ultrasonic longitudinal velocity values measured in the radial direction of the billet. The numbered end of the billet is at the bottom of the plot. $A=.106 \mathrm{in} / \mathrm{usec}$; $\mathrm{B}=.104-.105 \mathrm{in} . / \mathrm{usec} ; \mathrm{C}=.107-.108 \mathrm{in} . / \mathrm{usec}$. 


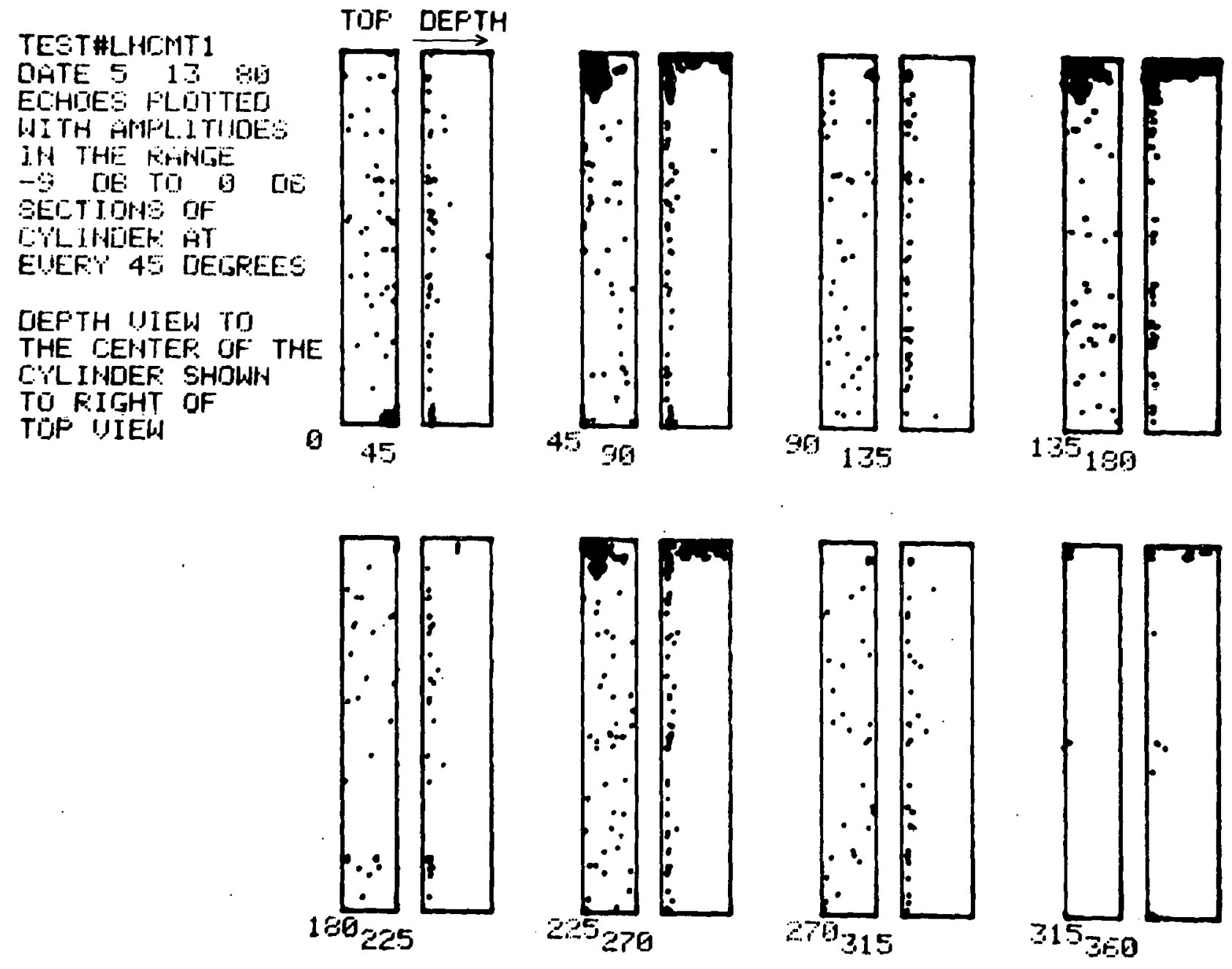

FIGURE A5. Pulse Echo Flaw Data in the radial direction of the billet. No flaws of cunsequence were recorded indicating a billet of good quality. 


\section{APPENDIX B}

Recorded Waveforms for CMT Specimens \#2, \#3, \#5, \#8, and \#9 as a Function of Increasing and Decreasing Temperature in Degrees Fahrenheit 


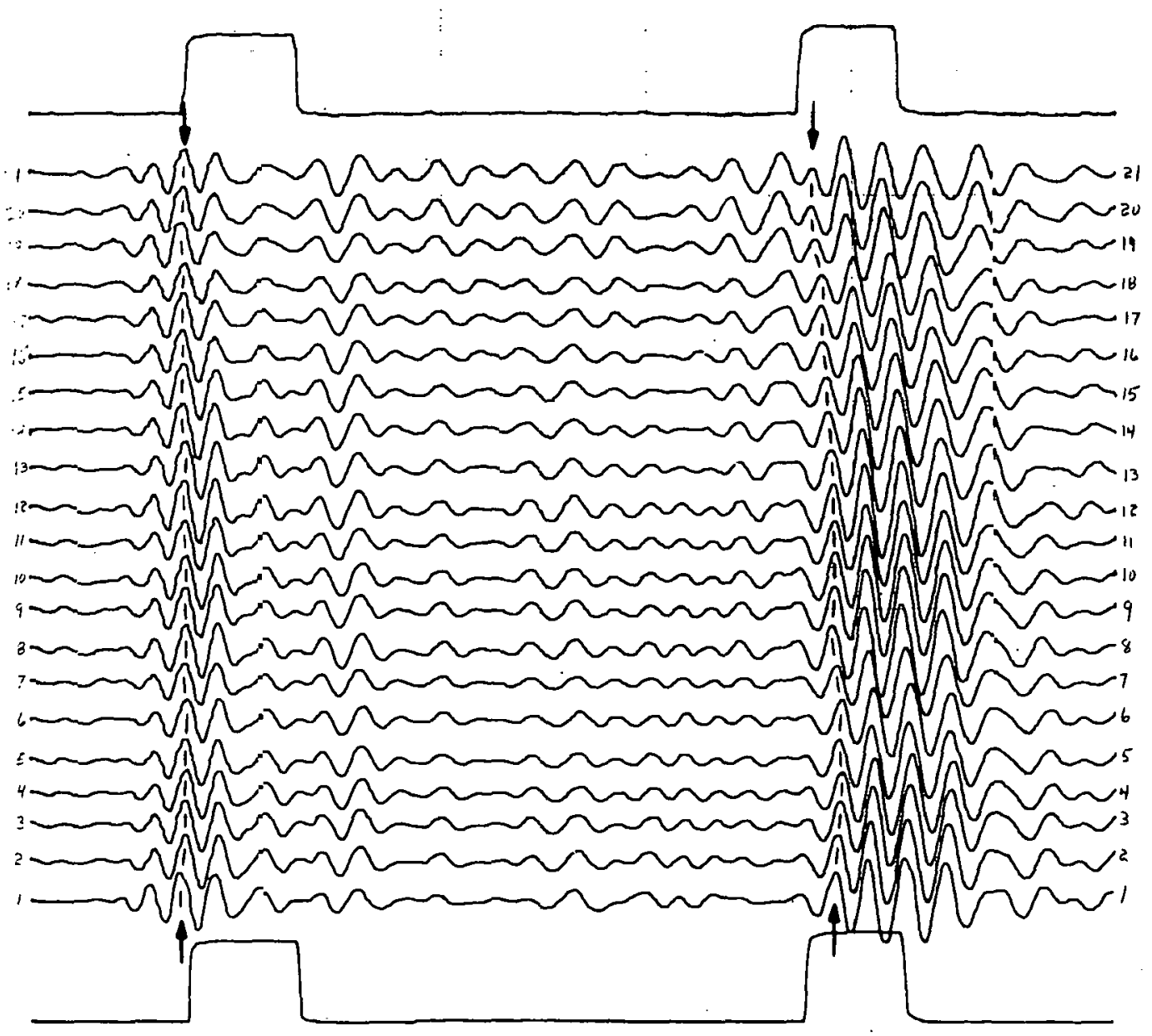

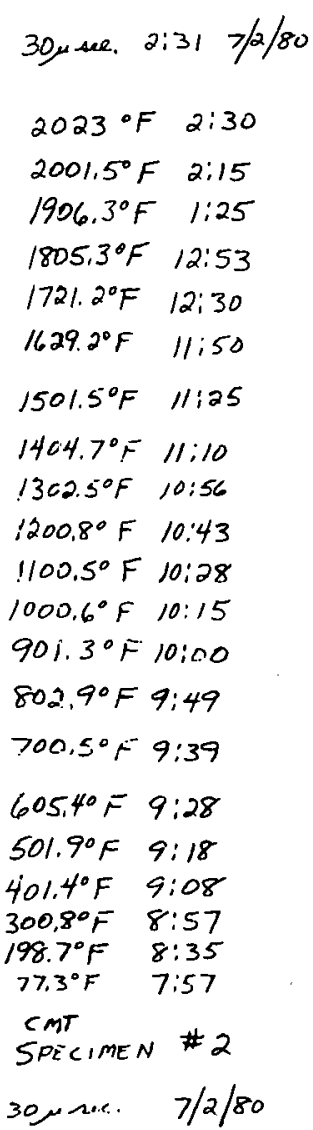

IICURE Bl. Palse Echo Waveforms showing echoes from gage section of 1.000 inch between milled slot and end of specimen \#2 for increasing temperatures. 


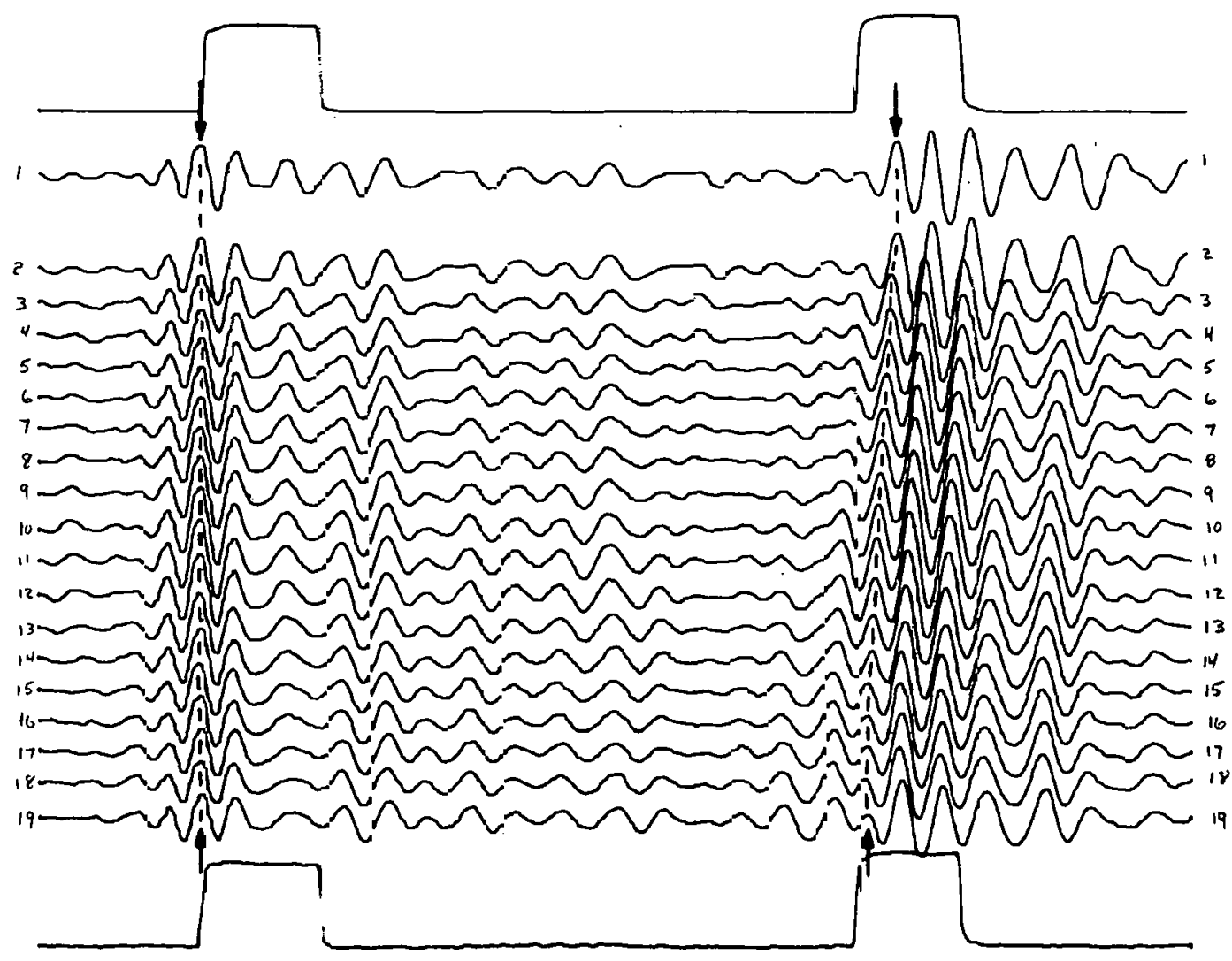

$30 \mu$ sec. CaLIB. $7 / 3 / 80$

$1836^{\circ} \mathrm{F}$

$2 \quad 83.6^{\circ} \mathrm{F} \quad 8: 04 \quad 7 / 3 / 80$

$3500^{\circ} \mathrm{F} 4: 28$

$4600^{\circ} \mathrm{F} \mathrm{4i19}$.

$5700^{\circ} \mathrm{F} \mathrm{4:08}$

$6 \quad 800^{\circ} \mathrm{F} 3: 59$

$7900^{\circ} \mathrm{F} 3: 49$

B $1000^{\circ} \mathrm{F} 3: 39$

$91100^{\circ} \mathrm{F} 3: 30$

$101200^{\circ} \mathrm{F} Z: 22$

$11300^{\circ}$ F $3: 15$

12 $1400^{\circ} \mathrm{F} 3: 08$

$131500^{\circ}$ F $3: 03$

$141600^{\circ} \mathrm{F} 2: 56$

$151700^{\circ} \mathrm{F} 2: 51$

$161800^{\circ} \mathrm{F} 2: 46$

$\begin{array}{lll}17 & 1900^{\circ} \mathrm{F} & 2: 42 \\ 18 & 2000^{\circ} \mathrm{F} & 2: 38\end{array}$

$192028.6^{\circ} \mathrm{F} \quad 2: 34$ SMET

$30 \mu$ Ne CALIB.

FIGUFE B2. Pulse Echo 'NEveforms skowing echoes from gage section of 1.000 inch between milled slot cnd end of specimen \#2 for decreasing temperatures. 


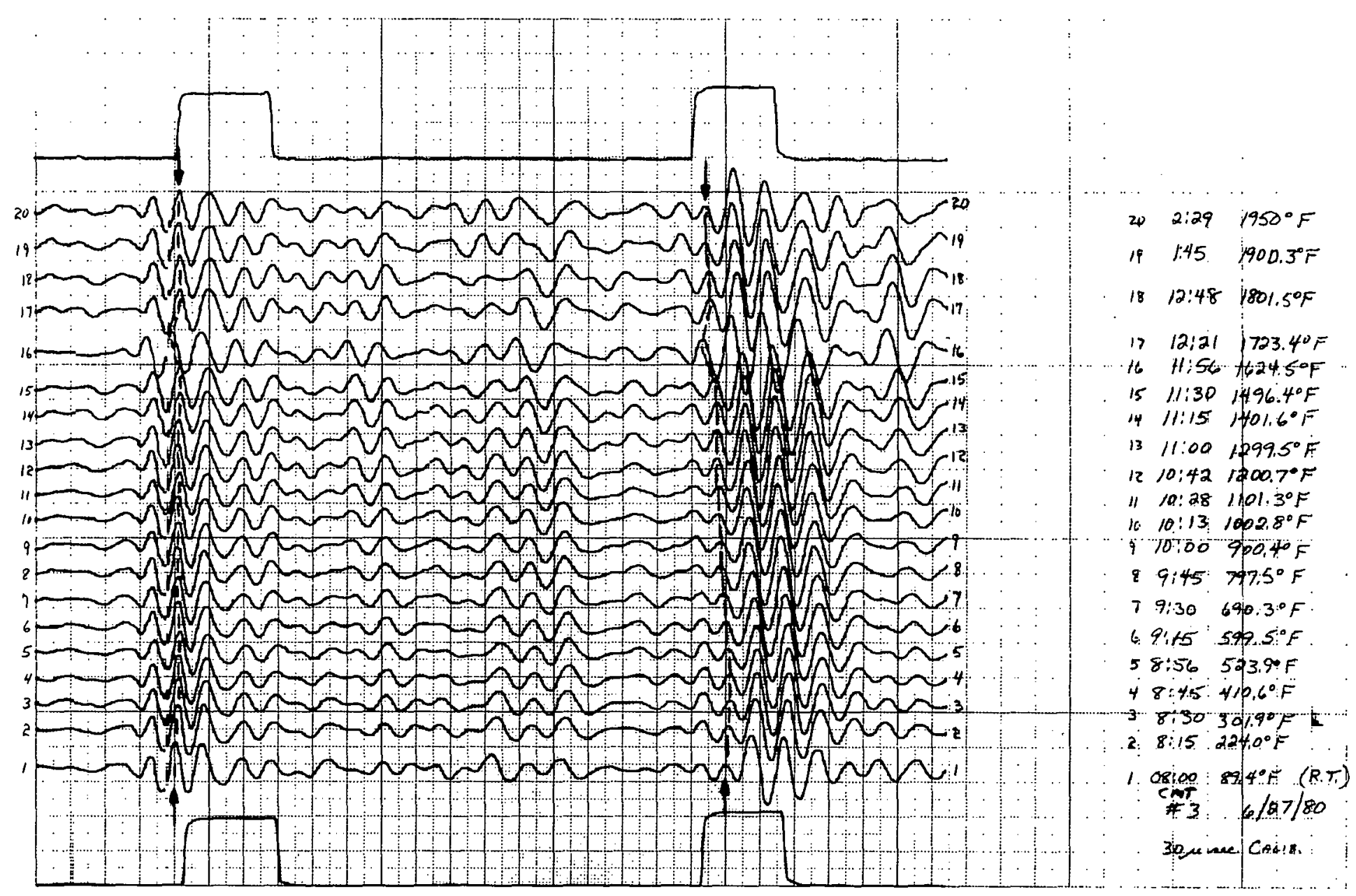

FIGURE B3. Pulse Echo Waveforms showing echoes from gage section of 1.000 inch between milled slot and end of specimen \#3 for increasing temperatures. 


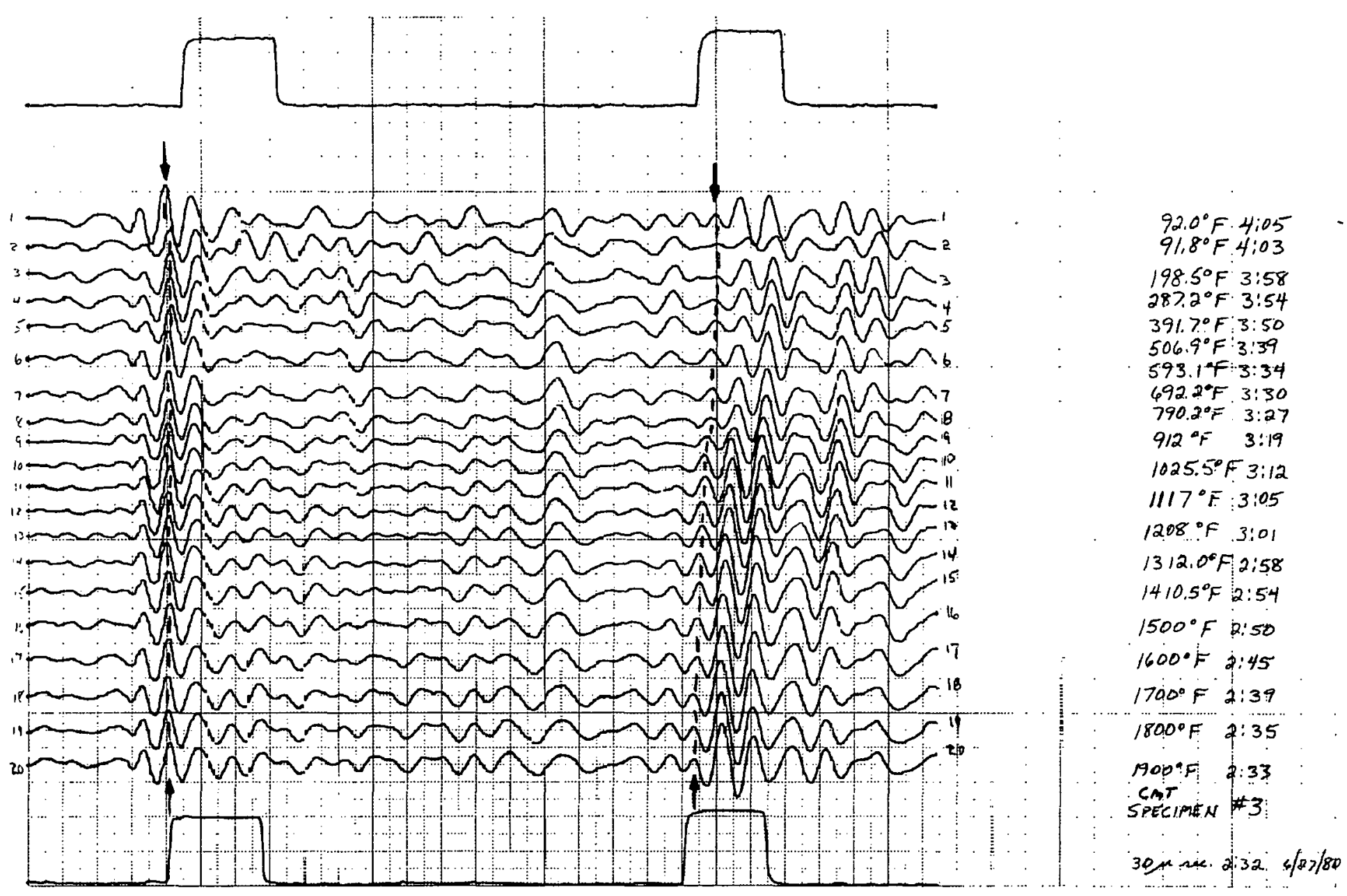

FIGURE B4. Zulse Echo Waveforms showing echoes from gage section of 1. 000 inch between rilled slot and end of specimen :'t3 for decreasing temperatures. 


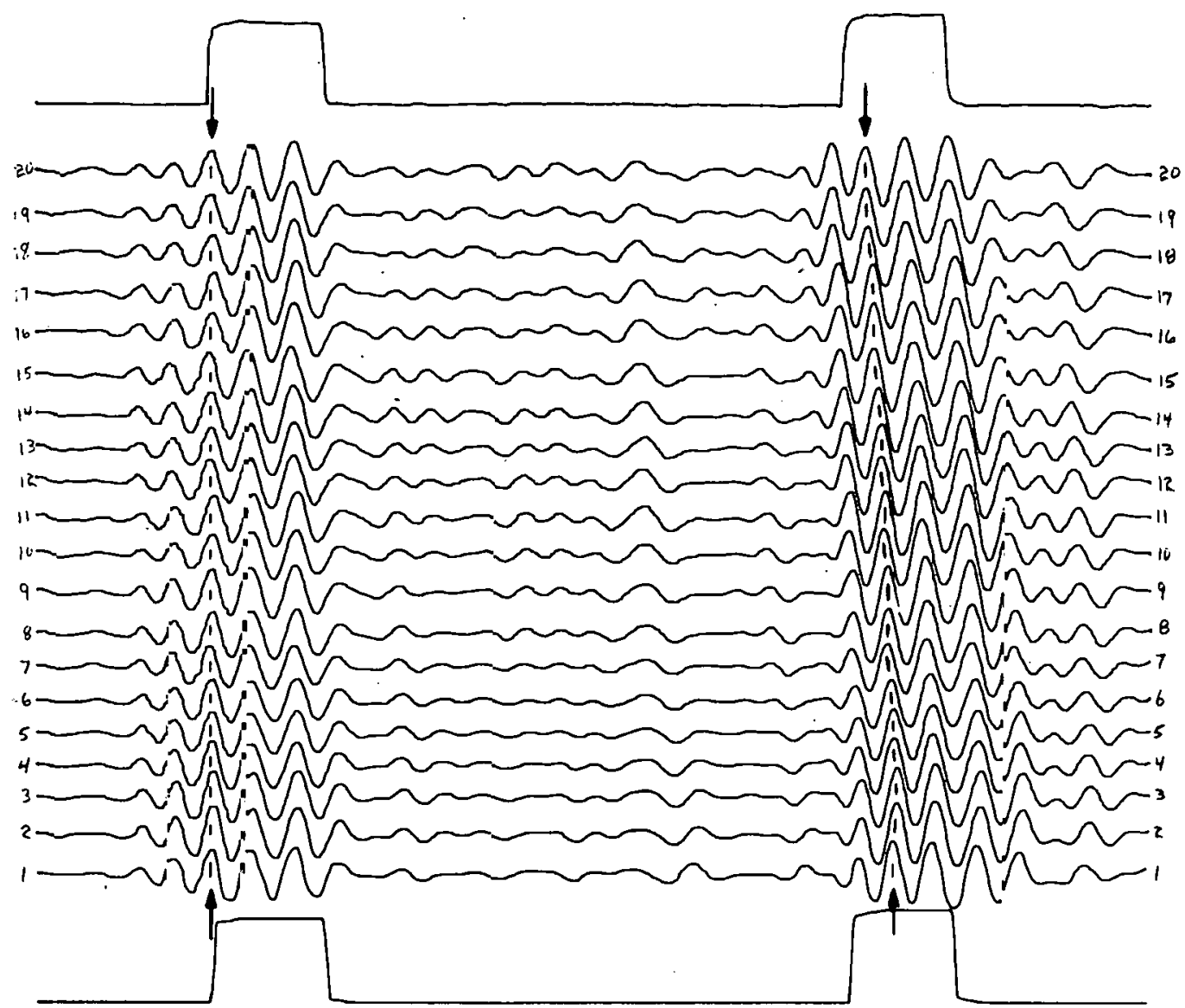

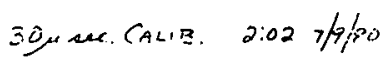

$30 \quad 1993.6^{\circ} \mathrm{F} \quad 2: 00$

19. $1900,80 \mathrm{~F} \quad 1: 17$

$18: 801.0^{\circ} \mathrm{F} \quad 12: 49$

$17 \quad 1718.90 \mathrm{~F} \quad 12: 31$

$161553.40 \mathrm{~F} \quad 11: 50$

If $1501.30 \mathrm{~F} \quad 11: 26$

$141401.20 \mathrm{~F} 11: 13$

$131301.9^{\circ} \mathrm{F} \quad 11: 00$

$12 \quad 1204.8^{\circ} \mathrm{F} \quad 10: 48$

$1100.60 \mathrm{~F} \quad 10: 34$

16. $1003.20 \mathrm{~F} \mathrm{10:16}$

$9900.6^{\circ} \mathrm{F} \quad 9: 58$

- 803.1\% $9: 45$

$7697.8^{\circ} \mathrm{F} \quad 9.30$

$6605,5^{\circ} \mathrm{F} \quad 9: 14$

$5498.7^{\circ} \mathrm{F}$ 5:00

$4403.0^{\circ} \mathrm{F} 8: 40$

$30 \Omega 2^{\circ} \mathrm{F}$ 8:.9.

$2305.5^{\circ} \mathrm{F} \quad 8: 10$

$179.6^{\circ} \mathrm{F} \quad 7: 55^{\circ}$

cmr Gmplite 5

30 sere. $7 / 9 / 80$

FIGURE B5. Pulse Echo Waveforms showing echoes from gage section of 1.000 inch between milled slot and end of specimen \#5 for increasing temperatures. 


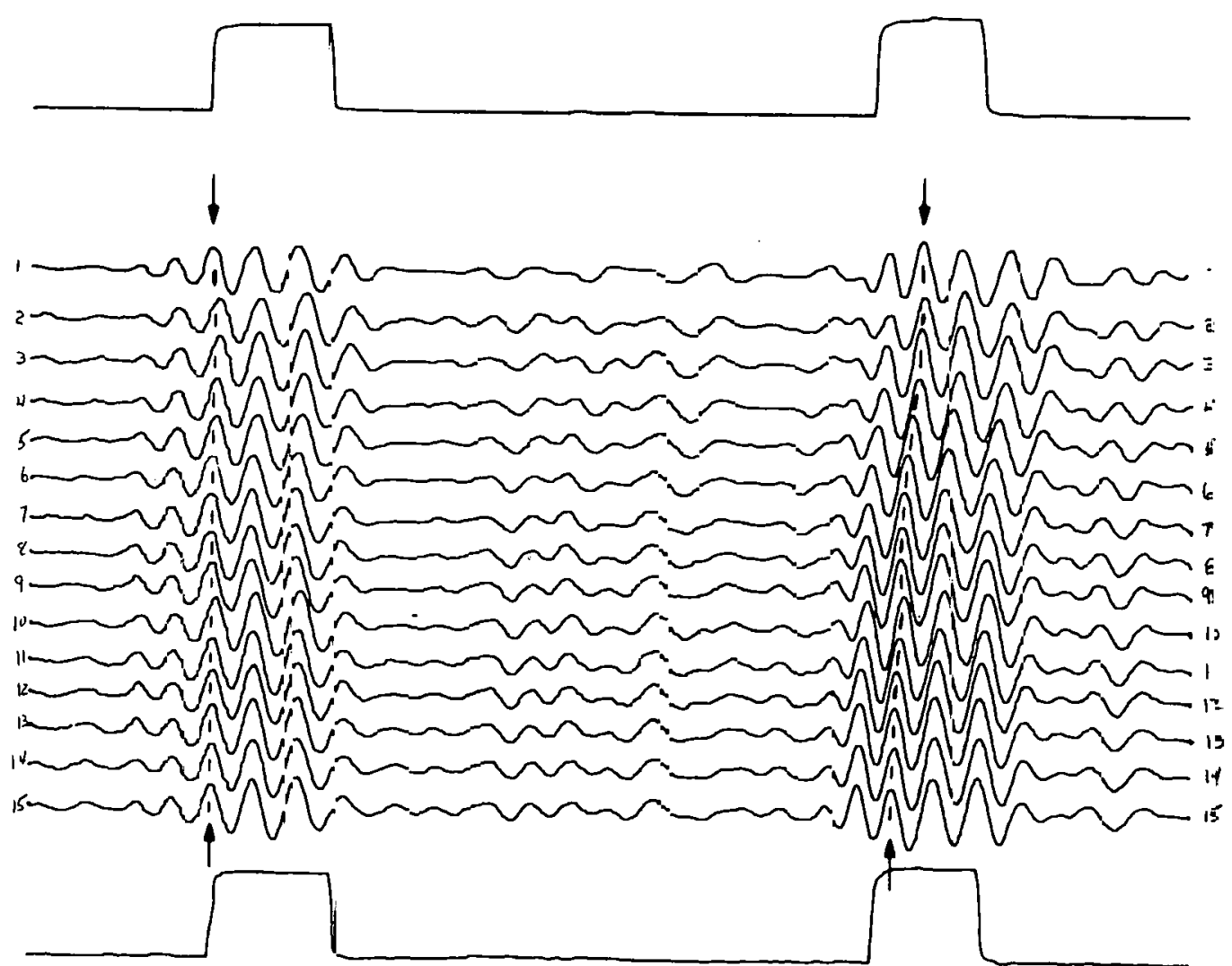

$30 \mu$ sec. CALIE.

FIGURE B6. Polse Eck. Waveform: showi.ng echoes from gage sectior of 1.000 inch between $\mathrm{m}=1$ led slot and end of spezimen \#5 for decreasing tenperatures. 


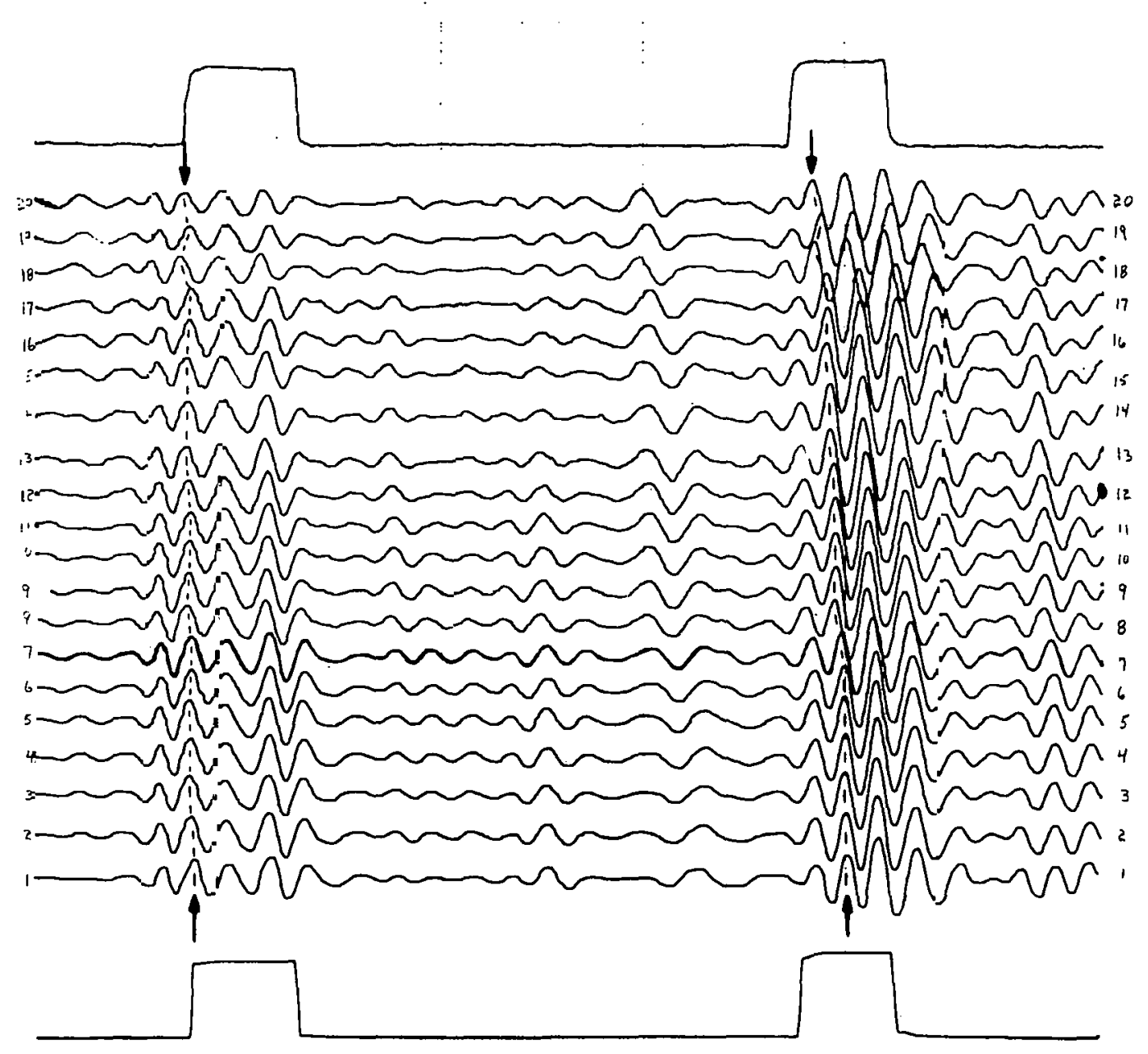

\begin{tabular}{|c|c|}
\hline $00,9^{\circ} \mathrm{F}$ & 2 \\
\hline $1900^{\circ} \mathrm{F}$ & $12: 39$ \\
\hline $1826.6^{\circ} \mathrm{F}$ & $12: 16$ \\
\hline $1708.90 \mathrm{~F}$ & $11: 48$ \\
\hline $1600.5^{\circ} \mathrm{F}$ & $11: 28$ \\
\hline $1500,9^{\circ} \mathrm{F}$ & $11: 10$ \\
\hline $1401.4^{\circ} \mathrm{F}$ & $10: 55$ \\
\hline $1301.3^{\circ} \mathrm{F}$ & $10: 43$ \\
\hline $1200.20 \mathrm{~F}$ & $10: 30$ \\
\hline $1100.3^{\circ} \mathrm{F}$ & $10: 15$ \\
\hline $1001.8^{\circ} \mathrm{F}$ & $10: 01$ \\
\hline $903.0^{\circ} \mathrm{F}$ & $9: 48$ \\
\hline $801.6^{\circ} \mathrm{F}$ & $9 ; 33$ \\
\hline $700.7^{\circ} \mathrm{F}$ & $9: 11$ \\
\hline $604.8^{\circ} \mathrm{F}$ & $8: 59$ \\
\hline $500.6^{\circ} \mathrm{F}$ & $8: 45$ \\
\hline $422.1 \cdot \mathrm{F}$ & $8: 35$ \\
\hline $335.1^{\circ} \mathrm{F}$ & $8: 21$ \\
\hline $2090 \mathrm{~F}$ & $8: 09$ \\
\hline $76.0^{\circ} \mathrm{F}$ & $7: 5=$ \\
\hline $\begin{array}{l}\text { CMT } \\
\text { SPECIMEN }\end{array}$ & $\$ 8$ \\
\hline
\end{tabular}

FIGURE B7. Pulse Echo Waveforms showing echoes from gage section of 1.000 inch between milled slot and end of specimen \#8 for increasing temperatures. 


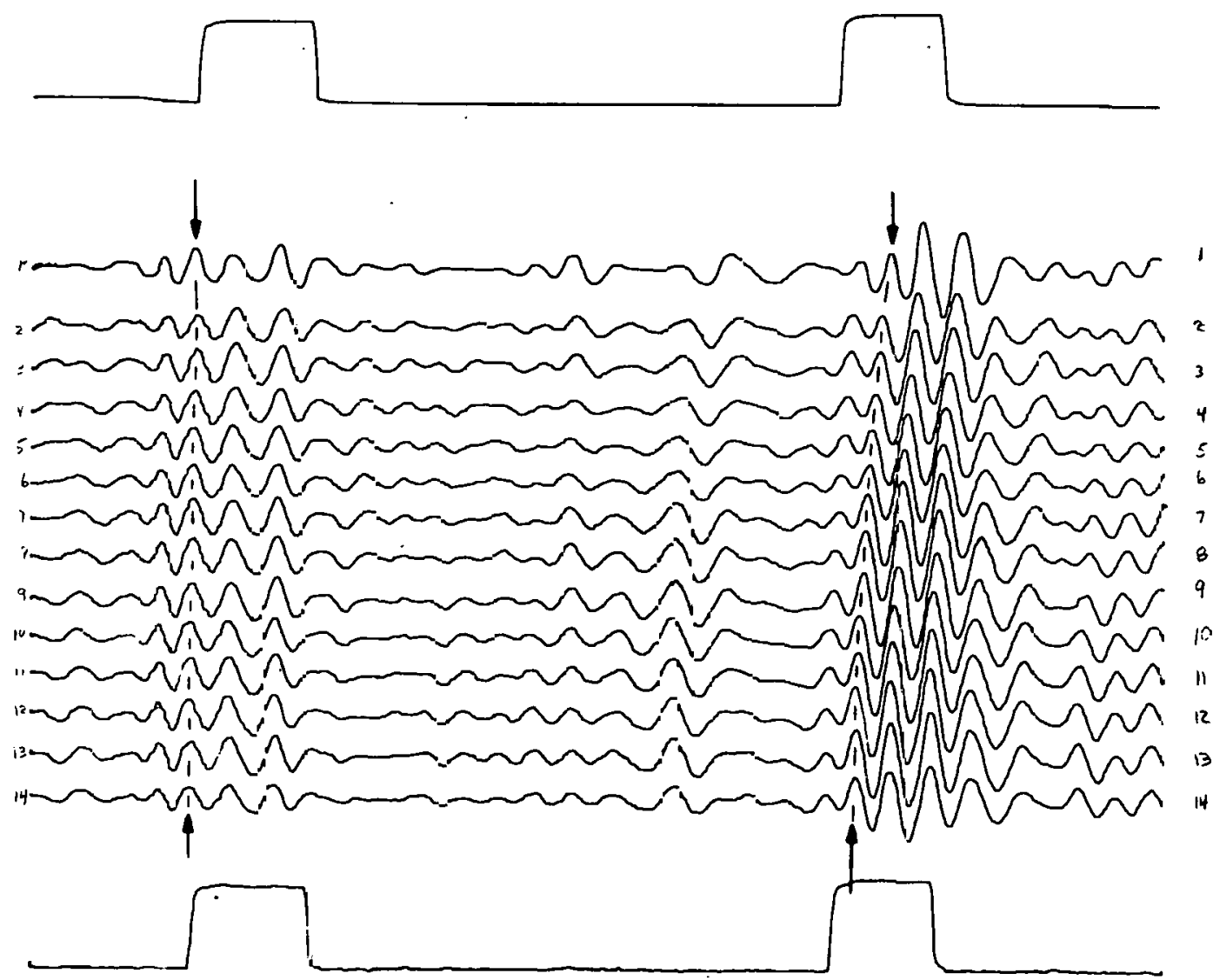

30pue. CALIB. $7 / 8 / 80$

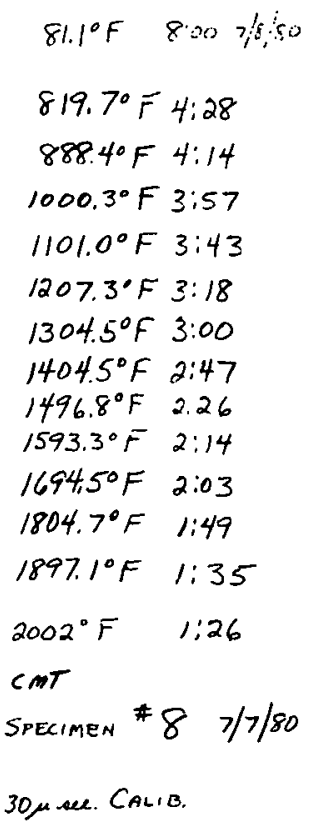

FIGURE B8. Pulse Echc Waveforms sirving echoes from gage section of 1.000 inch between milled slas and end of specimen \#8 for decreasing temperatures. 


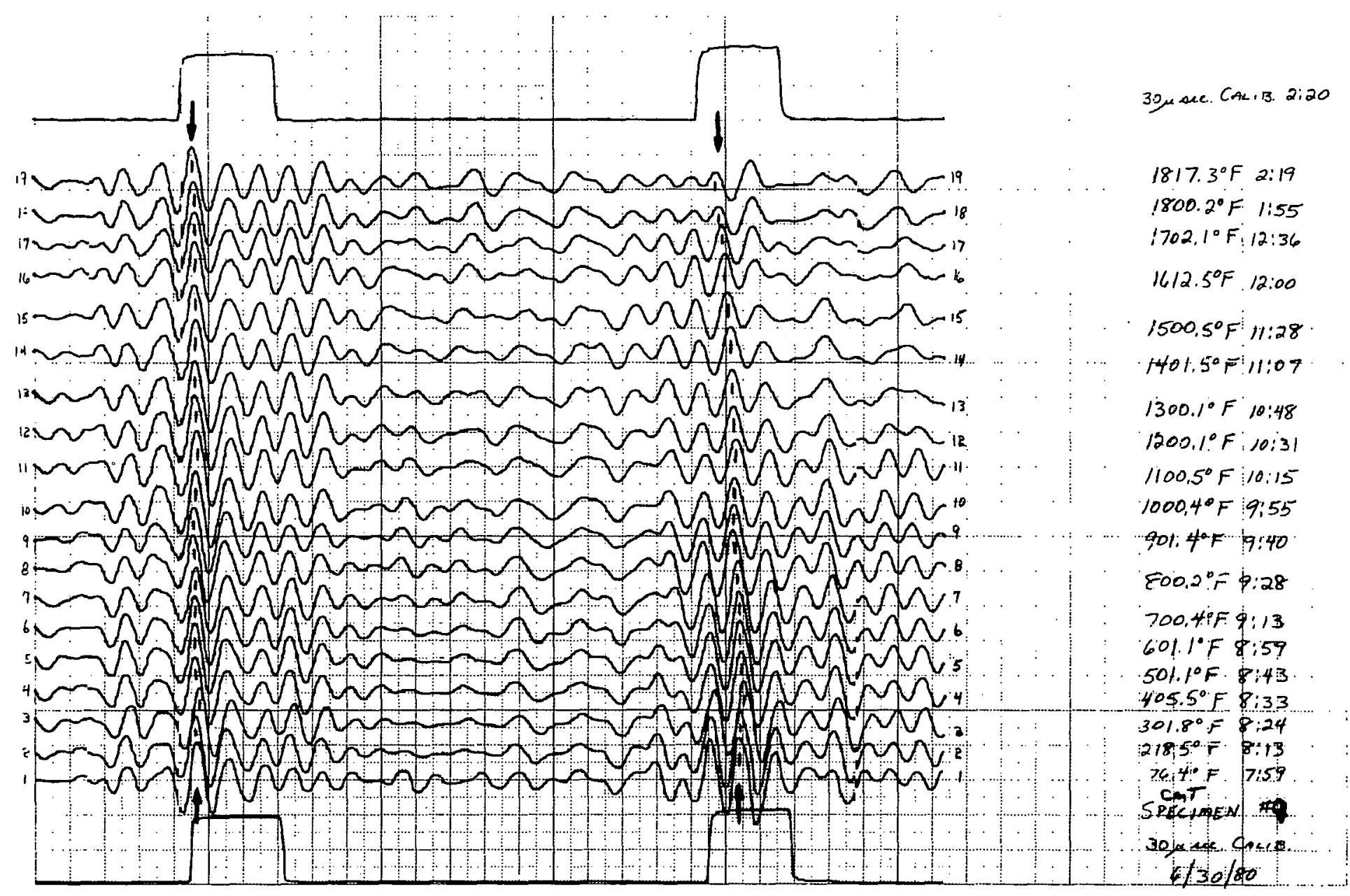

FIGJRE B9. Pulse Echo Waveforms showing echoes from gage section of 1.000 inch between milled slot and end of specimen \#9 for increasing temperatures. 


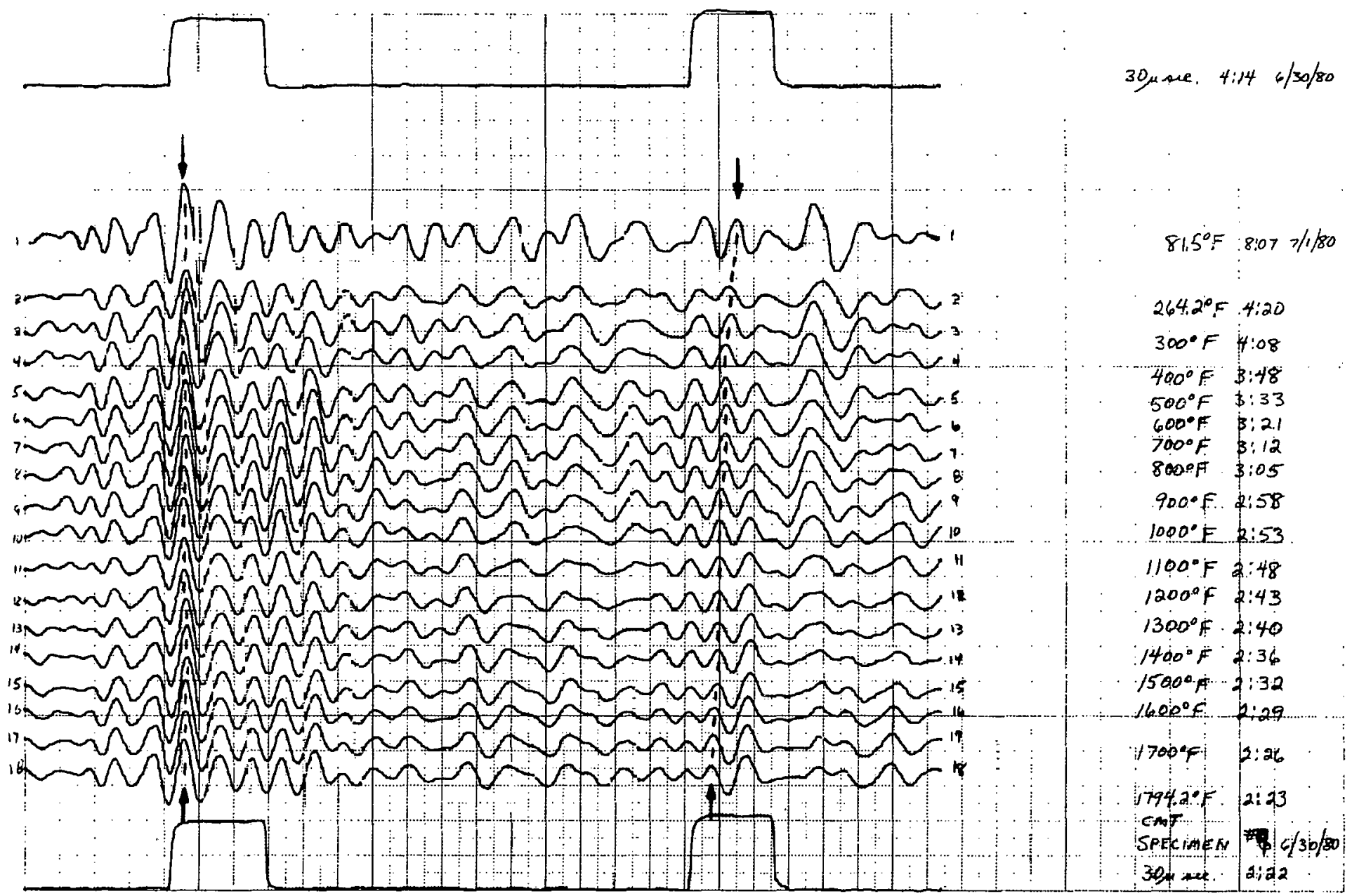

FIGURE B10. Plilse Echo Waveforms showing echoes from gage section of 1.000 inch between milled slot and end of specimen \#9 for decreasing temperatures. 


\section{REFERENCES}

1. J. H. Gieske, "UItrasonic Shear Wave Velocity in CMP Graphite Up To $6500^{\circ} \mathrm{F}, "$ SAND78-1448, Sandia Laboratories, Albuquerque, New Mexico, September 1978.

2. J. H. Gieske, "UItrasonic Velocity Determinations in ATJ-S Graphite Composite from $70^{\circ} \mathrm{F}$ to $6100^{\circ} \mathrm{F}$," SAND75-0043, Sandia Laboratories, Albuquerque, New Mexico, February 1975.

3. Y. J. Kaku, Lockheed Missiles and Space Company, Inc., Private Communication. 
DISTRIBUTION:

Unlimited Release

Lockheed Missiles \& Space Co. Inc.

P. O. Box 504

Sunnyvale, CA 94086

Attn: N. Nakashoji

D/81-21

Bldg. 154

400 C. Winter

1200 L. D. Smith

1400 L. J. Heilman

1500 W. A. Gardner

1550 F. W. Neilson

1551 D. W. Bullard

1552 O. J. Burchett

1552 J. H. Gieske (15)

4300 R. L. Peurifoy Jr.

4325 R. D. Christopher

5520 T. B. Lanc

5623 D. J. Rigali

Attn: J. L. Irwin

5800 R. S. Claassen

8266 E. A. Aas

8310 D. M. Schuster

8444 A. R. Willis (2)

3141 T. L. Werner (5)

3151 W. L. Garner (3)

For: DOE/TIC

DÜE/'LIL'

(Unlimited Release)

(R. P. Campbel1, 3154-3) (25) 


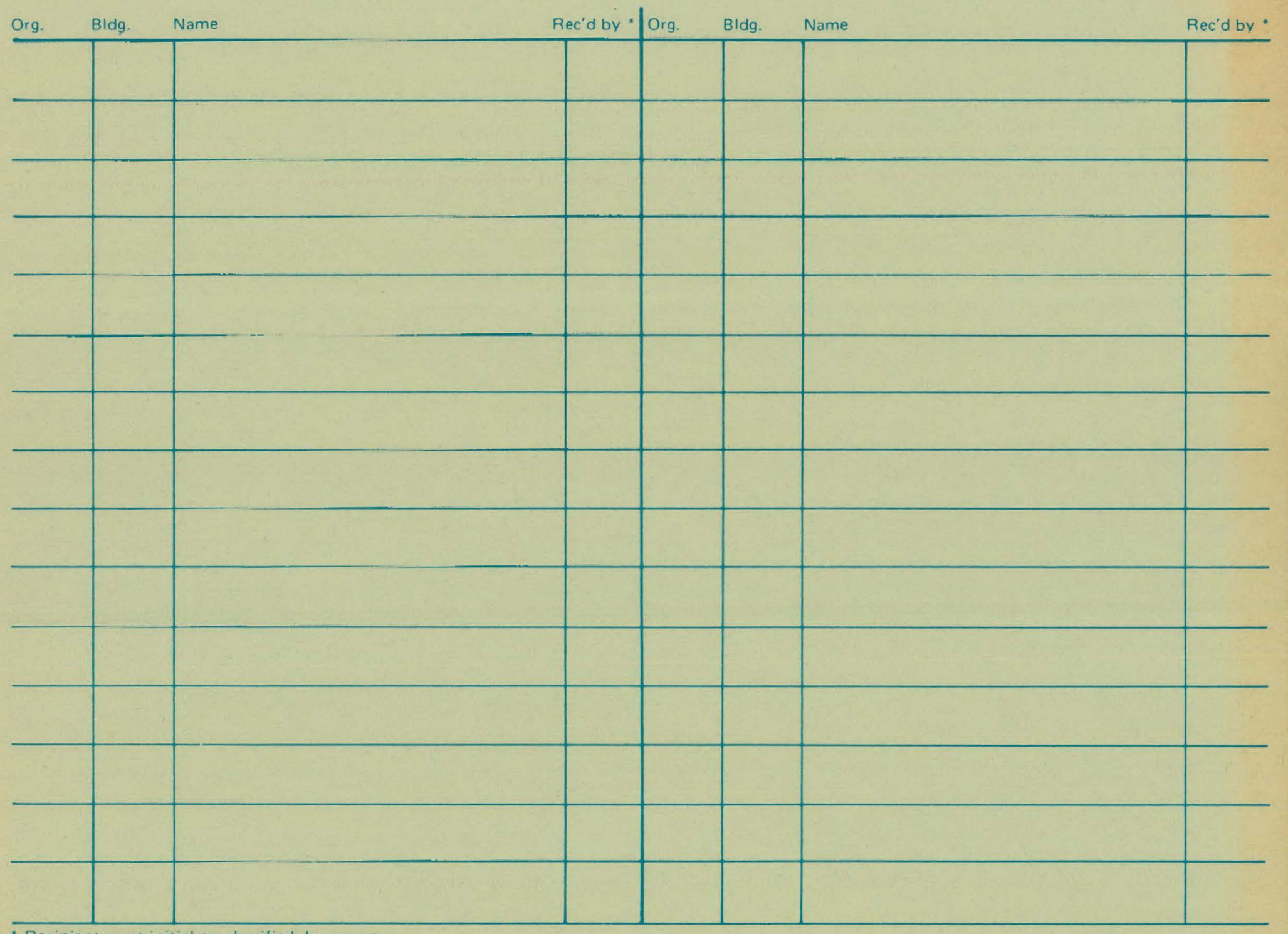

